1 López-Merino L, Silva Sánchez N, Martínez Cortizas A, Kaal J and López-Sáez JA. 2012. Post-

2 disturbance vegetation dynamics during the Late Pleistocene and the Holocene: An example

3 from NW Iberia. Global and Planetary Change 92-93: 58-70.

4

\title{
Post-disturbance vegetation dynamics during the Late Pleistocene and the Holocene: an example from NW Iberia
}

8 Lourdes López-Merino ${ }^{1 *}$, Noemí Silva Sánchez², Joeri Kaal ${ }^{3}$, José Antonio López-Sáez ${ }^{4}$, 9 Antonio Martínez Cortizas ${ }^{2}$

111 Institute for the Environment, Brunel University, Uxbridge, London, Middlesex UB8 3PH (UK),

12 lolome@hotmail.es, Lourdes.Lopez-Merino@brunel.ac.uk

132 Departamento de Edafología y Química Agrícola, Facultad de Biología, Universidad de Santiago.

14 Campus Sur, 15782 Santiago de Compostela (Spain), noemi.silva.sanchez@usc.es, 15 antonio.martinez.cortizas@usc.es

$16{ }^{3}$ Instituto de Ciencias del Patrimonio (Incipit), Consejo Superior de Investigaciones Científicas (CSIC),

17 San Roque 2, 15704 Santiago de Compostela (Spain), joeri@incipit.csic.es

$18{ }^{4}$ G.I. Arqueobiología, Instituto de Historia (CCHS), Consejo Superior de Investigaciones Científicas 19 (CSIC), Albasanz 26-28, 28037 Madrid (Spain), joseantonio.lopez@cchs.csic.es

*Corresponding author: lolome@hotmail.es, Lourdes.Lopez-Merino@brunel.ac.uk

\section{Abstract}

There is a wealth of studies dealing with the reconstruction of past environmental changes and their effects on vegetation composition in NW Iberia, but none of them have focussed specifically on the post-disturbance dynamics (i.e. the type of response) of the vegetation at different space and time scales. To fill this gap, we analysed the record of pollen and non-pollen palynomorphs (NPP) of a 235$\mathrm{cm}$ thick colluvial sequence spanning the last $\sim 13,900$ years. The aims were to detect the changes in vegetation, identify the responsible drivers and determine the type of responses to disturbance. To extract this information we applied multivariate statistical techniques (constrained cluster analysis and principal components analysis on transposed matrices, $P C A_{t r}$ ) to the local (hydro-hygrophytes and NPP) and regional (land pollen) datasets separately. In both cases the cluster analysis resulted in eight local and regional assemblage zones, while five (local types) and four (regional types) principal components 
identified were climate change, grazing pressure, fire events and cultivation. The vegetation showed gradual, threshold and elastic responses to these drivers, at different space (local vs. regional) and time scales, revealing a complex ecological history. Regional responses to perturbations were sometimes delayed with respect to the local response. The results also showed a ecosystem resilience, such as the persistence of open Betula-dominated vegetation community for $\sim 1700$ years after the onset of the Holocene, and elastic responses, such as the oak woodland to the 8200 cal yr BP dry/cold event. Our results support the notion that palaeoecological research is a valuable tool to investigate ecosystem history, their responses to perturbations and their ability to buffer them. This knowledge is critical for modelling the impact of future environmental change and to help to manage the landscape more sustainably.

Key-words: palynology; vegetation composition; vegetation response; principal component analysis; transposed matrix; Holocene; NW Iberia.

\section{Introduction}

Environmental and climatic changes were frequent during the Late Quaternary; some even relatively abrupt (Mayewski et al., 2004). Many of them have been reliably recorded by environmental archives in the form of long-term records, which contain key information that offers a unique opportunity to study the patterns of ecological change (Willis et al., 2010; Williams et al., 2011). Among these records those related to vegetation dynamics are the most investigated. As with any other natural system, vegetation has some resilience to withstand environmental change. However, the capacity to buffer changes, either natural or anthropogenic, varies at different spatial and time scales, and sometimes involves gradual or abrupt modifications/reorganisations of the structure and functioning in response to perturbations (Holling, 1973; Dearing, 2008). Thus, there is an obvious need to understand the post-disturbance responses of vegetation since disturbance is a key factor structuring its composition. As Ritchie (1986: 72) proposed "The central issue of palaeoecologists is to measure accurately the response of vegetation to environmental change and to express differing patterns of response in quantitative terms".

Carrión et al. (2010a) outlined the patterns of vegetation change for the Late Quaternary in the Iberian Peninsula, emphasising the strong regional differences, mainly related to the Eurosiberian and Mediterranean biogeographical regions. While in the Mediterranean region a large heterogeneity in vegetation change has been pointed out, in the Eurosiberian one, comprising the north and northwest, as well as in other areas with Atlantic 
71 influence, a more homogeneous picture has emerged. Moreover, in the Eurosiberian area the vegetation change generally follows the Central European floristic model, where a rapid spread of mesophytic species occurred at the onset of the Holocene. Overall, the last $\sim 14,000$ years of palaeoenvironmental and vegetation changes in NW Iberia have been investigated using a variety of proxies, including pollen, non-pollen palynomorphs (NPP), charcoal, plant macroremains, diatoms, geochemistry and molecular markers, in several types of archives such as lacustrine deposits (Allen et al., 1996; Santos et al., 2000; Muñoz Sobrino et al., 2001, 2004; Leira and Santos, 2002; Jalut et al., 2010; Moreno et al., 2011; López-Merino et al., 2011a), mires (Muñoz Sobrino et al., 1997; Martínez Cortizas et al., 1999, 2005; Mighall et al., 2006; López-Merino et al., 2010a, 2011b; Morales-Molino et al., 2011; Schellekens et al., 2011), colluvial soils (Kaal et al., 2008, 2011; Costa Casais et al., 2009; Carrión et al., 2010b), coastal sediments (Santos and Sánchez-Goñi, 2003; García-Amorena et al., 2007), marine sediments (Desprat et al., 2003; Muñoz Sobrino et al., 2007a), and archaeological deposits (López-Sáez et al., 2003, 2009; López-Merino et al., 2010b). These studies were mainly undertaken in mountain areas and showed complex histories where climate, fire, vegetation change and human activities, e.g. animal husbandry, agriculture and mining, were ultimately responsible for past and current landscape configuration (Ramil-Rego et al., 1998; Muñoz Sobrino et al., 2005, 2007b; Martínez Cortizas et al., 2005, 2009). Briefly, from the onset of the Holocene to $\sim 2000$ years ago forests expanded and were important in the landscape. Indicators of human impact started to appear around $\sim 7600$ years ago, increasing at $\sim 4500$ years cal BP with widespread phases of deforestation since Roman times onwards (Jalut et al., 2010). But despite the many studies focussing upon past vegetation, climate trends and impact of human activities, investigations comparing vegetation composition and post-disturbance dynamics are lacking. The same is true for other parts of the Iberian Peninsula, with notable exceptions for the SE of Iberia. Firstly, the study of the pollen record of Siles Lake by Carrión (2002), which covers the last $\sim 20,300$ years, showed gradual, rapid and threshold responses, which involved complete changes in forest composition, as well as abrupt shifts at the local scale, pointing towards hydroclimatic variations. Moreover, lags in vegetation development in comparison with limnological stages were identified at the centennial scale. Secondly, in another study carried out by Carrión et al. (2001) in the Villaverde Lake, timelags in vegetation response to environmental change were detected, especially in response to climate amelioration at the beginning of the Holocene, pointing towards the resilience of established Pinus populations during $\sim 2200$ years, as well as decadal shifts in the pollen record since the mid-Holocene. Finally, Gil-Romera et al. (2010a) defined ecosystem functioning and resilient 
behaviour at long-term time scales at two sites. At Zoñar, it seems that disturbance promoted changes in biodiversity and landscape structure, shifting from one state to another; while in Gádor several stable phases linked to arid conditions and the spread of the grassland were detected.

In other parts of Europe a similar picture emerges, as only a few long-term ecological studies have focused upon vegetation response and most of them do not contextualise the type of response to perturbation. Some exceptions include the research done by Tinner et al. (2000) in the Alps, in which they identified several possible responses of plants to fire of medium and high frequency; by Hellberg et al. (2003) in Sweden, where vegetation dynamics and disturbance history has been detected in several deciduous forests; or by Feurdean et al. (2010) in Romania, where they explored the potential driving factors for the vegetation change in eight pollen datasets, but also the response of the vegetation at different spatial and time scales in the sense of differentiation and homogenization, i.e. reduction or increase in similarity, an increasingly important feature for modern-day conservation plans. However, in other parts of the world this approach has been applied more often, i.e. the disturbance history of a Tsugadominated forest in New England (Massachusetts, Foster and Zebryk, 1993), the threshold responses and differential resilience behaviour of vegetation to environmental perturbation in Madagascar (Virah-Sawmy et al., 2008), and the alternating open and encroaching phases in the Ethiopian savannah that showed a non-linear response to environmental change (GilRomera et al., 2010b; also see Willis et al., 2010; Gil-Romera et al., 2010a for more examples). All the examples stress the importance of such knowledge for conservation and management of ecosystems and to better assess the consequences of future changes.

In this paper we present a palynological study of a colluvial soil (PRD-4), spanning the last $\sim 13,900$ years, sampled in Campo Lameiro (Pontevedra, NW Iberia). Campo Lameiro is considered a suitable site because, apart from the fact that it is located in an archaeological area with one of the most important collections of pre-historic rock art in Europe, several studies developed there recently (e.g. Kaal et al., 2008, 2011; Costa Casais et al., 2009; Carrión et al., 2010b; Kaal, 2011) showed that colluvial soils are suitable archives for palaeoenvironmental research. The objectives of this work were to i) detect changes in the vegetation composition and their drivers, and ii) decipher the post-disturbance dynamics, at regional and local scales. In addition, in order to get statistical information about vegetation composition and response to environmental change, novel multivariate analyses were applied.

\section{Materials and methods}




\section{$140 \quad$ 2.1. Study area}

142 The PRD-4 sequence is located in the Rock Art Park of Campo Lameiro (42032'N $8^{\circ} 31^{\prime} \mathrm{W}$, 143 Pontevedra, NW Spain, Fig. 1), in a local depression on the isolated hill Monte Paradela (260-

$144320 \mathrm{~m}$ a.s.l.). The area is located in the Atlantic/Eurosiberian climate region, with mild (mean 145 annual temperature of $15^{\circ} \mathrm{C}$ ) and humid (mean annual precipitation of $1200 \mathrm{~mm}$ ) climatic 146 conditions (Martínez Cortizas and Pérez Alberti, 1990). Currently, Pinus pinaster, Quercus 147 robur, Pteridium aquilinum and heathlands with different species of Erica and Calluna vulgaris 148 are the main components of the vegetation, with remnants of Eucalyptus globulus plantations, 149 Ulex and Cytisus, which are periodically eliminated since 2003 with the setting up of the 150 archaeological park. In the valleys, the riparian vegetation is composed of inter alia Alnus 151 glutinosa, Corylus avellana, Fraxinus excelsior, Ulmus glabra, Populus, Betula alba and 152 Crataegus monogyna.

153

\section{$154 \quad$ 2.2. Sampling and palynological analysis}

155

156 A soil monolith (PRD-4, $235 \mathrm{~cm}$-thick, Fig. 2) was sampled from a trench and sliced into $5 \mathrm{~cm}$ 157 sections. Samples were treated following the classic chemical methodology (Moore et al., 158 1991) to obtain pollen, spores and other NPP with concentration in heavy liquid (Goeury and de 159 Beaulieu, 1979). Palynological counting was conducted at 400x under the light microscope, 160 and the average total land pollen sum (TLP) was 575 terrestrial pollen grains, excluding hydro161 hygrophytes and NPP (expressed as percentages of the TLP). The average sum of hydro162 hygrophytes and NPP was 170 palynomorphs. Palynomorphs were well preserved and no 163 taphonomic problems were detected. The identification was aided by the reference collection of 164 the Archaeobiology laboratory (CCHS, CSIC, Madrid), identification keys and atlases (Moore et 165 al., 1991; Reille, 1992). NPP classification follows the nomenclature proposed by the Hugo de 166 Vries (HdV) laboratory of the University of Amsterdam. Pollen diagrams were obtained using 167 TILIA (Grimm, 1992, 2004).

168

\section{$169 \quad$ 2.3. Radiocarbon dates and chronology}

171 Six samples were selected for ${ }^{14} \mathrm{C}$ dating using the AMS technique. The ${ }^{14} \mathrm{C}$ dates (Table 1 ) 172 were calibrated using the IntCaL09.14C calibration curve (Reimer et al., 2009). The age-depth 
model was obtained using the Clam software developed by Blaauw (2010), using a smoothspline solution. According to this model, the $235 \mathrm{~cm}$ represents the last $\sim 13,900$ years (Fig. 3).

\subsection{Separating local and regional taxa}

In this study we consider the taxa included in the TLP as related to a regional signal, while hydro-hygrophytes and NPP as components of the local signal. When we refer to regional vegetation we mean close regional. Distinguishing local from regional vegetation in a soil sequence, compared to sequences from wetlands such as mires and lakes, is challenging. In the latter, the local vegetation communities can be identified, but in colluvial soils this approach is not as straightforward. However, NPP can be safely considered as local indicators as their dispersal is limited. The case of the hydro-hygrophyte taxa is more complex, as they could also be part of the regional communities. The PRD-4 sequence is located in a small depression, so variations in moisture and water availability could be responsible for differences in local communities. For this reason, we have included the hydro-hygrophytes into the local signal as they follow patterns related to those found for the NPP (Fig. 4), i.e. maximum development of Cyperaceae, Filicales and Ranunculaceae are synchronous with Spirogyra and Mougeotia, while maximum values of Pteridium aquilinum and Polypodium vulgare type are coeval with the presence of Coniochaeta cf. ligniaria, Coniochaeta xylariispora and Anthostomella cf. fuegiana. However, it is important to remind that this separation is just an approach, a model to try to understand the changes at different scales. In fact, previous anthracological research (Kaal et al., 2011) demonstrated that woody vegetation was abundant at the margins of the small basin, and that ferns were components of the forest. With the proposed separation into regional and local, we want to extract general trends taking into account the spatial limitations cited here. As an example, in pollen research done in peatlands the general approach is to consider the Ericaceae (Erica and Calluna) as a component of the regional vegetation, when some species are frequent components of bog communities. The same problem applies to Poaceae, as it is also considered as a regional indicator, or Cyperaceae, considered as local, when both could be part of regional and local communities. But, although with limitations, we believed the established categories enable to assess the main general trends and, therefore, the separation of signals proposed could be a valid approach when combined with multivariate statistics.

\subsection{Statistical analyses}


When working with large datasets of environmental proxies, multivariate methods are helpful to

208 reduce the dimensionality or group/classify samples. With such techniques it is possible to

209 avoid extensive descriptions of results, making the interpretation and explanation of the

210 observed patterns easier in terms of underlying processes operating at relevant spatial and

211 time scales (Birks, 1985). Thus, to extract the information of the local and regional proxies we

212 applied multivariate statistical techniques. Stratigraphically constrained cluster analysis by the

213 method of total sum of squares (Grimm, 1987) was used to define local and regional

214 palynological zones, which are based on changes (in terms of Euclidian distance) in the pollen

215 assemblages between consecutive samples. These zones are usually interpreted as shifts in

216 vegetation composition. Two cluster analyses were performed: one for regional taxa, including

217 the types considered in the TLP; and another for local taxa, including hydro-hygrophytes and

218 NPP. As such, the data comprised 41 and 24 taxa, respectively. Percentage values were used

219 after the palynological data were re-summed to $100 \%$ for the taxa not included in the TLP (local

220 signal). Thus the purpose was to perform two independent zonations that enable the 221 comparison between the results of local and regional proxies.

222 In addition, principal component analysis (PCA) was used to describe the main 223 features of the palynological record and get insights into the representativeness of changes in 224 vegetation composition through time and the type of response to environmental change. Again, 225 separate analyses were performed for regional and local taxa, both on the transposed data 226 matrices ( $\left.P C A_{t r}\right)$; that is, with samples in columns (variables) and taxa in rows (cases). This 227 approach is intuitive to interpret palynological data from an ecological point of view, and it 228 enables summarizing the palynological composition of the samples based on co-variation 229 patterns. Correlation matrices were used, and varimax rotation solutions were applied to 230 constrain the co-variation in the components. PCA analyses were done using SPSS 15.0.

231 Due to the fact that the number of palynomorphs in the local signal is lower than the 232 number of types in the regional signal, the reliability of the statistical results is of concern. 233 However, the average of the local sum is 170 , and the average number of taxa per sample is 234 10.6, not too low if we consider that the number of counted NPP is often lower in most 235 palynological studies. Nonetheless, some samples have low local sums, mainly at the bottom 236 and the top of the sequence (24-49 palynomorphs), but the taxonomic diversity is not much 237 lower in these samples (6-12 different taxa), so that we believe that the results of the statistical 238 analysis are representative and significant.

239 The use of a transposed matrix demands a careful interpretation of some key concepts 240 associated to conventional PCA, typically applied to non-transposed datasets (i.e. samples as 
241 rows and variables as columns). This is because, contrary to the usual focus of the PCA, i.e.

242 the co-variation of taxa, with $\mathrm{PCA}_{\mathrm{tr}}$ we detect the co-variation of samples, i.e. the co-variation of

243 the palynological assemblages of the different soil sections/age periods. This allows for the

244 comparison of samples taking into account their palynological composition and the

245 characterization of assemblages of co-existing principal taxa, i.e. ecological groups composing

246 the palynological record, as well as their importance in each sample/age period. For each

247 principal component, the taxa showing large factor scores (i.e. larger abundances) are those

248 explaining most of the variation of the pollen and NPP signal in samples with large factor 249 loadings (Silva Sánchez, 2010). Thus, the PCAtr approach allows the identification of 250 assemblages of palynomorphs with statistically significant contribution to the total variance, and 251 to express quantitatively for each sample the proportion of variance of its composition 252 explained by each principal component (i.e. significant assemblages of palynomorphs). These 253 two aspects are valuable for defining vegetation composition and for assessing the type of 254 response. Regarding the type of responses, we distinguished between gradual, threshold and 255 elastic ones on the basis of the PCA $A_{t r}$ results. i) Threshold when a complete change from one 256 sample to the next is detected, in terms of the main principal component (i.e. palynological 257 assemblage) explaining most of the variance of the palynological composition of the samples.

258 ii) Gradual, when the change detected in the composition of the vegetation implies the decline 259 of the importance of one principal component and the increase of another. This change could 260 involve a complete or partial replacement of the principal component (i.e. vegetation formation) 261 explaining the variance of the palynological composition of the samples. iii) Elastic, when a 262 complete recovery of the previous palynological composition occurs after a short-term 263 disturbance. Additionally, we have included the term of "sensitivity" for those cases where the 264 cluster analysis identified the boundary of a palynological zone but the PCA $A_{t r}$ did not suggest a 265 change in the vegetation composition.

\section{Results and interpretation}

\subsection{Local signal}

271 Eight Local Assemblage Zones (LAZ) were detected by cluster analysis (Fig. 4) while five 272 principal components explained $94.1 \%$ of the total variance in the dataset. The percentage of 273 the variance explained by each principal component can be seen in Table 2, and the

274 fractionation of communalities and the factor scores are represented in Figs. 5 and 6. 
In LAZ-1 (235-210 cm; $13,900-12,370$ cal yr BP) the fourth principal component

276 (PC4L) explains most of the variance (65-96\%) of the palynological composition of samples

277 (Fig. 5), with Pleospora commanding the largest positive factor score (Fig. 6). Pleospora is a

278 fungal ascospore and has been found in relatively dry sections of ombrotrophic peat (van Geel,

279 1978; Yeloff et al., 2007). PRD-4 is a black, organic-rich, colluvial soil, but the ascospores 280 could still be related to dry conditions.

281 LAZ-2 $(210-185 \mathrm{~cm} ; \sim 12,370-10,670 \mathrm{cal}$ yr BP$)$ is characterised by the first principal 282 component $\left(\mathrm{PC} 1_{\mathrm{L}}\right)$, explaining most of the variance (63-95\%) of this zone (Fig. 5). Cyperaceae 283 is the taxon with the largest positive factor score (Fig. 6). The expansion of sedges represented 284 a major change in the palynological composition at local scale (Fig. 5) and it is most likely 285 related to more humid (or wetter?) conditions.

286 LAZ-3 $(185-140 \mathrm{~cm} ; \sim 10,670-7580 \mathrm{cal}$ yr BP$)$ is also characterised by the dominance 287 of $P C 1_{L}$, reflecting the consolidation of Cyperaceae. It accounts for most of the variance (92$28896 \%$ ), except at a depth of 160-155 cm (32\%; Fig. 5). The emergence of Spirogyra and 289 Mougeotia (van Geel, 1978) and increased percentages of ferns (Fig. 4) seem reflect a shift 290 towards more humid conditions. At 160-155 cm ( 8920-8620 cal yr BP), PC3 ${ }_{L}$ and PC4L also 291 explain a significant part of the variance (40 and 13\%, respectively, Fig. 5). PC4L indicates dry 292 conditions, while in PC $3_{\llcorner}$Pteridium aquilinum is the taxon with the largest positive factor score 293 and Coniochaeta xylariispora has a moderate negative factor score (Fig. 6). Thus, at this depth, 294 PC3L reflects an abrupt short-term shift in this zone between sedges and bracken, but also 295 indicates an opposite pattern between Pteridium aquilinum and Coniochaeta xylariispora, which 296 may reflect woodland opening and accumulated dead wood, respectively. Moreover, the 297 punctual presence of Glomus in this sample could be related to erosion linked to drier 298 conditions.

299 In LAZ-4 (140-100 cm, 7580-4800 cal yr BP), PC1 1 still explains most of the variance 300 (36-94\%), but with increasing proportions accounted by PC3 (3-56\%; Fig. 5), indicating a more 301 or less gradual replacement of Cyperaceae by Pteridium aquilinum. The detection of 302 coprophilous fungi, such as Sordaria-type, Sporormiella-type, Podospora-type and Cercophora303 type (Fig. 4), suggests that this change could be related to grazing activities in the local 304 surroundings. Moreover, the abundance of macroscopic (>2 mm) charcoal particles (from 305 hereon charcoal, Fig. 2) increased simultaneously with the appearance of grazing indicators.

306 From 100 to $45 \mathrm{~cm}$, corresponding to zones LAZ-5 to LAZ-7, charcoal concentration 307 increased (Fig. 2), most of which originated from deciduous Quercus (Kaal et al., 2011). LAZ-5 $308(100-70 \mathrm{~cm} ; \sim 4800-3400 \mathrm{cal}$ yr BP) is characterised by the second principal component (PC2L), 
which explains the vast majority of the variance in the pollen composition of this zone (71-94\%; Fig. 5). Polypodium vulgare type has a large positive score, while Coniochaeta xylariispora has a moderate positive score (Fig. 6). The increase in charcoal fragments in this zone is not associated to grazing activities, as they are not recorded in tandem with synanthropic pollen and coprophilous fungal spores (Figs. 4 and 7), but could be climate-induced, although human activities with purposes other than animal husbandry could have also been important.

In LAZ-6 (70-55 cm; 3400-2510 cal yr BP), PC2L also explains most of the variance (63-85\%), although the fifth principal component (PC5L) increases in importance throughout the zone (8-26\%; Fig. 5). For PC5L, Pseudoschizaea and Polypodium vulgare type have large positive factor scores, while Coniochaeta xylariispora, Coniochaeta cf. ligniaria and Anthostomella cf. fuegiana have large negative factor scores (Fig. 6). Polypodium vulgare type continues to be the main taxon in the local vegetation although soil erosion is inferred from the presence of Pseudoschizaea. Soil erosion was probably exacerbated by grazing (renewed appearance of coprophilous fungi) and the lack of arboreal tree cover (low arboreal pollen percentages; Fig. 7).

In LAZ-7 (55-45 cm; 2510-1830 cal yr BP), PC2L dominates the record (55-57\%), although PC3L is also important (25-28\%; Fig. 5). Thus, Polypodium vulgare type and Pteridium aquilinum are the best represented local taxa. In this zone, the maximum concentration of charcoal particles was detected (Fig. 2).

Finally, local zone LAZ-8 (45 cm-top; 1830 cal yr BP-present) is heterogeneous and could reflect a phase of structural reorganization of the vegetation following long-term fire perturbation, as charcoal concentrations declined. At the beginning of the zone, $\sim 1830-1200$ cal yr BP, PC2L and PC5 $L_{L}$ explain most of the variance (30-37\% and $27-34 \%$, respectively; Fig. 5), pointing towards an increase in soil erosion (Pseudoschizaea) and the persistence of Polypodium vulgare type. After this short-term episode, PC3 $\mathrm{L}$ explains most of the variance (41$69 \%$ ), and PC2 abundance in Polypodium vulgare type while Pteridium aquilinum increased. In the top sample $\mathrm{PC} 1_{\mathrm{L}}$ (Cyperaceae) is important again, explaining $52 \%$ of the variance (Fig. 5).

\subsection{Regional signal}

Eight Regional Assemblage Zones (RAZ) were detected with the cluster analysis (Fig. 7) while four principal components explained $96.6 \%$ of the total variance. The percentage of the 
variance explained by each principal component can be seen in Table 3, and the fractionation of the communality and the factor scores are given in Figs. 8 and 9, respectively.

In RAZ-1 (235-210 cm, $13,900-12,370$ cal yr BP) the second principal component (PC2R) explains most of the variance (91-98\%; Fig. 8). Betula has the largest positive factor score, while Poaceae and Cytisus/Ulex type also have positive scores and deciduous Quercus a moderate negative score (Fig. 9). Although these pollen types are the taxa that show the largest statistical association to this zone, Artemisia, Chenopodiaceae and Juniperus are also present (Fig. 7) and they are indicative of dry, cold conditions.

In RAZ-2 (210-185 cm; 12,370-10,670 cal yr BP) the PC2 $\mathrm{R}$ still explains most of the variance $(79-89 \%)$, indicating the persistence of the Betula open woodland, but with increasing loadings of $P C 1_{R}(6-10 \%)$ and $P C 3_{R}$ (4.5-10.4\%; Fig. 8). In $P C 1_{R}$ deciduous Quercus has a large positive factor score, while other mesophytes such as Corylus, Alnus and Betula have moderate ones, while Poaceae has a negative moderate score (Fig. 9). In PC $3_{R}$, Poaceae shows the largest positive factor score; deciduous Quercus and Cistus ladanifer have moderate scores, while Betula, Corylus and Pinus show moderate negative scores. Both $P C 1_{R}$ and $P C 3_{R}$ would be indicative of a slight incipient spread of both closed $\left(P C 1_{R}\right)$ and open oak $\left(P C 3_{R}\right)$ forests.

In RAZ-3 (185-155 cm; 10,670-8620 cal yr BP), while PC2 ${ }_{R}$ still explains part of the variance $(25-48 \%), P C 1_{R}$ becomes more important $(49-71 \%$ of the variance; Fig. 8$)$. In contrast, in the top sample of the zone ( 8920-8620 cal yr BP) PC1 $1_{\mathrm{R}}$ only explains $13 \%$ while the $\mathrm{PC} 2_{\mathrm{R}} 73 \%$ of the variance. In general, this zone shows a gradual replacement of Betula by deciduous Quercus forest, but by the end of this zone open Betula woodland becomes more important. As found for the local vegetation, the latter could be related to a short-term abrupt shift in environmental conditions.

RAZ-4 and -5 represent the consolidation of the deciduous oak forest. In RAZ-4 (155$130 \mathrm{~cm}$; 8620-6870 cal yr BP) PC1 $1_{R}$ explains most of the variance (81-90\%), with $P C 2_{R}$ accounting for only a minor part (3-14\%; Fig. 8). This implies that the deciduous Quercus forests were extensive and only some remnants of the "cold vegetation", more abundant in previous stages, still persisted. In RAZ-5 (130-100 cm; 6870-4800 cal yr BP), PC1 $1_{\mathrm{R}}$ continues to explain most of the variance (86-93\%; Fig. 8). It is noteworthy that, although in RAZ-5 the oak forest is well developed, indicators of human pressure such as Plantago lanceolata type, Plantago major/media type, Urtica dioica type and Rumex acetosella type were also detected (Fig.7). Additionally, at a local scale, an increase in coprophilous fungi was also detected at $140 \mathrm{~cm}$ ( 7580 cal yr BP).The local vegetation underwent some changes (see above), but 
apparently these were minor at the regional scale as they did not affect the overall composition of the regional forest and it seems that only a small reduction of the arboreal cover occurred (Fig.7).

In RAZ-6 (100-55 cm; 4800-2510 cal yr BP), PC1 loses significance gradually (18$84 \%$ of the variance) while $P C 3_{R}$ shows increasing percentages (12-61\%; Fig. 8). This may imply a gradual response of the regional vegetation to the intensification in the fire regime, as suggested by the increase in charcoal concentration (Fig. 2) and the substitution of the mature oak forest by an open oak forest with an increasing expansion of grass- and shrubland. Moreover, palynological indicators of grazing activities (coprophilous fungi, Plantago lanceolata type, Plantago major/media type and Urtica dioica type) are detected from $70 \mathrm{~cm}$ depth ( 3400 cal yr BP), suggesting there was a phase of fires without simultaneous grazing disturbance beforehand ( 4800-3400 cal yr BP).

In RAZ-7 (55-35 cm; $\sim 2510-1200$ cal yr BP) the open oak forest is the dominant vegetation community, as PC3R explains most of the variance (53-70\%) of the samples (Fig. 8). A reduction in charcoal concentration was observed for the top $45 \mathrm{~cm}$ of the soil sequence (from 1830 cal yr BP; Fig. 2), although a change in the regional vegetation is not recorded until $\sim 1200$ cal yr BP when grazing indicators lose their importance (Fig. 7). At that time a complete change in the vegetation composition defines the onset of RAZ-8 (35 cm-top; 1200 cal yr BP-present). PC4R explains most of the variance (29-87\%) of the samples (Fig. 8). Erica type has a large positive factor score, while Pinus sylvestris type, Pinus pinaster and Calluna have moderate positive scores. Thus they reflect the spread of heathland and pine occurring during the last few centuries. Additionally, Eucalyptus pollen has also been found in this zone (Fig. 7).

\section{Vegetation composition and post-disturbance vegetation dynamics}

Several features from the results described above are worth of emphasising (Fig. 10). First, complex ecological histories reflected by changes in the vegetation composition were detected at both local and regional scales, because multiple drivers were operating across different space and time scales. Second, gradual, threshold and elastic responses occurred during the last millennia. And, third, the regional response to a perturbation was sometimes delayed with respect to the local response.

\subsection{Onset of the Holocene, non-equilibrium forests and the $8200 \mathrm{cal}$ yr BP event}


411 In the PRD-4 record, the shift towards warmer conditions during the onset of the Holocene was 412 dated at $\sim 12,370$ cal yr BP, which, taking into account the uncertainties of an extrapolated age 413 (no radiocarbon date for the bottom sample of the sequence), matches well with previous 414 studies in NW Iberia (i.e. Allen et al., 1996; Muñoz Sobrino et al., 2001, 2005, 2007b; Carrión et 415 al., 2010a; Moreno et al., 2011). At the local scale a main change in the palynological 416 composition from the pre-Holocene dominance of Pleospora $\left(\mathrm{PC}_{\mathrm{L}}\right)$ to Cyperaceae $\left(\mathrm{PC} 1_{\mathrm{L}}\right)$ after 417 the onset of the Holocene is interpreted as a threshold response (Fig. 10). At the regional 418 scale, although the vegetation was sensitive to the change in environmental conditions (the 419 cluster analysis distinguishes a RAZ suggesting a change in the pollen record), an open 420 landscape with Betula $\left(\mathrm{PC}_{2}\right)$ persisted, with only a minor, incipient, increase of the 421 mesophilous trees ( $\mathrm{PC}_{\mathrm{R}}$ ) (Fig. 10). The regional persistence of an open landscape with Betula 422 reflects the resilience of the established Late Pleistocene vegetation to the onset of the 423 Holocene, and indicates that such vegetation could persist in a state of non-equilibrium with 424 climate for $\sim 1700$ years.

At $\sim 10,670$ cal yr BP a shift towards more humid conditions can be inferred from the presence of Spirogyra and Mougeotia and virtual disappearance of Pleospora (Fig. 4), which is 427 probably related to the onset of the Hypsithermal/Holocene Thermal Maximum. Although the 428 change was recorded, it seems that the increase in humidity did not cause a significant 429 variation in the local palynological assemblage, as $\mathrm{PC1}$ (Cyperaceae) was still the main 430 principal component. At the regional scale a gradual response is suggested by a shift from the 431 open landscape with Betula $\left(P C 2_{R}\right)$ to a denser oak-dominated forest ( $P C 1_{R}$; Fig. 10). The 432 change in vegetation composition points to a gradual spread of the oak forest; however 433 remnants of the Late Pleistocene vegetation were still present. It is likely that the regional 434 vegetation was near its ecological limit and more humid, and probably warmer, conditions 435 prompted a change in the forest.

436 An abrupt short-lived change in the structure of the vegetation has been detected at $437 \sim 8920-8620$ cal yr BP. At a local scale Pteridium aquilinum spread as the main taxon (PC3L), 438 while at regional scale the open landscape with Betula $\left(P C 2_{R}\right)$ became re-established (Fig. 10). 439 Both are considered to be short-term disturbances in which the vegetation showed an elastic 440 response, as its composition (both local and regional) completely recovered thereafter (Fig. 441 10). This short-term perturbation is likely to be related to the cold 8200 cal yr BP event. 442 Although the chronology in PRD-4 is somewhat older, the difference can be assumed within the 443 uncertainty of the age-model. In fact, in other pollen records of NW Iberia similar short-term 
444 forest reductions have been detected and related with this cold event (i.e. Muñoz Sobrino et al.,

$4452004,2005,2007 b)$. At the regional scale, the oak forest $\left(P C 1_{R}\right)$ had expanded after the short446 term perturbation and the remnants of the open-landscape with Betula $\left(P C 2_{R}\right)$ almost 447 disappeared.

\subsection{Fire events, grazing pressure and the origin of the heathland}

450

451 Indicators of cattle grazing and fires were detected from approximately $\sim 7580$ cal yr BP (Figs.

4524,7 and 10). At the local scale, these perturbations represented the initiation of a gradual 453 response where Cyperaceae $\left(\mathrm{PC}_{\mathrm{L}}\right)$ decreased in abundance while Pteridium aquilinum started 454 to spread (PC3L). Bracken easily colonizes disturbed ground, including burnt areas (Salvo, 455 1990), and the charcoal record provides unequivocal evidence of fires (Fig. 10). However, at 456 the regional scale the well-established oak forest did not show any significant change until $457 \sim 6870$ cal yr BP (Fig. 10), when a sensitive response was detected on the basis of the cluster 458 analysis. Although a decrease in the arboreal pollen (Fig. 7) and an increase in charcoal (Kaal 459 et al., 2011) occurred, this sensitivity did not invoke a major change in the composition of the 460 regionally dominant oak forests $\left(P C 1_{R}\right)$. This might reflect the upslope reduction in arboreal 461 vegetation but intact downslope vegetation communities (Carrión et al., 2010b). By $\sim 4800$ cal 462 yr BP evidence of decreased grazing pressure while the fire regime intensified (higher 463 concentration of charcoal particles, Fig.10) is detected. Humidity indicators such as Spirogyra 464 and Mougeotia almost disappeared, indicating local dry conditions, probably related to the end 465 of the Hypsithermal/Holocene Thermal Maximum. The new environmental conditions may have 466 been responsible for the inferred responses at both scales (Fig. 10). At the local scale a 467 threshold response is suggested by the shift to an almost complete dominance of Polypodium 468 vulgare type and Coniochaeta xylariispora (PC2L). The fern is likely to grow on dead trunks (in 469 particular after forest fires) while the fungus has been related to the presence of charcoal 470 particles (Blackford et al., 2006; Yeloff et al., 2007) (Fig. 2). At the regional scale the response 471 was gradual with closed oak woodland $\left(\mathrm{PC1}_{\mathrm{R}}\right)$ evolving into an open forest, and the spread of 472 Poaceae and, since $\sim 3400$ cal BP, of Cistus ladanifer (PC3R) (Fig. 10). These results for the 473 period between $\sim 4800-3400$ cal yr BP can be summarized as a regional reduction of forest 474 cover and expansion of ferns and herbaceous species caused by increased fire activity (yet 475 negligible grazing pressure). The shift to locally drier conditions might suggest that the cause of 476 these changes was climatic -this chronology broadly coincides with the Neoglaciation, as found 477 in other records from NW Iberia (Martínez Cortizas et al., 1999; López-Merino et al., 2010a) - 
478 but further research, taking into account the information of nearby environmental records and 479 archaeological findings, is necessary to confirm it. In the nearby PRD-2 soil sequence the 480 overall picture is slightly different, as coprophilous fungi are present in the record since $\sim 5500$ 481 cal yr BP, indicating local grazing (Carrión et al., 2010b). But between 4000 and 3500 cal yr 482 BP a change in the composition occurred, with increased abundance of Sporormiella-type, 483 while Sordaria-type was more frequently recorded before $\sim 4000$ and after 3500 cal BP. From $484 \sim 4000$ to 3500 cal yr BP there was an intensification of the fire regime, probably indicating 485 changes in landscape management.

$486 \quad$ Multiple responses were identified at PRD-4 after $\sim 3400$ cal yr BP. At the regional 487 scale a more open oak forest was dominant between $\sim 2510$ cal yr BP and $\sim 1200$ cal yr BP 488 (PC3 , Fig. 10), the period with the lowest percentages of arboreal pollen of the whole record 489 (Fig. 7), and for which the maximum concentration of charcoal was found (Fig. 10). In general, 490 a renewed increase in grazing (indicated by coprophilous fungi, Plantago lanceolata type, 491 Plantago major/media type and Urtica dioica type) occurred accompanied by increased soil 492 erosion (Pseudoschizaea, PC5 $5_{\mathrm{L}}$ ). Pteridium aquilinum (PC3 $\mathrm{L}$ ) expanded even though 493 Polypodium vulgare type (PC2 $\mathrm{L}$ ) remained the dominant taxon, providing further evidence of 494 local grazing impact. Furthermore, by $\sim 1830 \mathrm{cal}$ yr BP the intensity of the fire regime strongly 495 diminished, although not disappearing, and at the local scale an internal, post-disturbance 496 restructuring of the vegetation took place in three stages: i) Polypodium vulgare type / 497 Pseudoschizaea (i.e. erosion), ii) Pteridium aquilinum / Polypodium vulgare type, iii) 498 Cyperaceae / Pteridium aquilinum. In the last stage (top sample), the palynological composition 499 is dominated by Cyperaceae (PC1 $\left.1_{L}\right)$ and Pteridium aquilinum ( $\left.P C 3_{\mathrm{L}}\right)$, which were the main taxa 500 prior to the period characterised by an intense fire regime, indicating an elastic response of the 501 local vegetation. However, at the regional scale there was no such immediate shift in the 502 system, although by $\sim 1200$ cal yr BP a threshold response is characterised by the abrupt 503 spread of heathland ( $\mathrm{PC}_{\mathrm{R}}$ ) coeval with the decrease in grazing indicators and greater 504 importance of pine and, somewhat later ( $800 \mathrm{cal}$ yr BP), cereal crops (Figs. 4 and 7$)$. This 505 delayed response at the regional scale could be explained by the fires being localised and/or 506 by the oak woodland showing resilience until other drivers amplified the effects of the changing 507 environmental conditions (e.g. lower grazing pressure and perhaps the start of crop cultivation). 508 Heathland is a common feature of the current landscape of NW Iberia, but there are significant 509 differences in the chronology and intensity of the replacement of deciduous woodlands by 510 heathlands. In PRD-2, fire and grazing induced forest regression and Ericaceae/Fabaceae 511 shrubland expansion was significant by around $\sim 500$ cal yr BP, and the complete colonisation 
512 of the area by heathland was detected in the pollen record at $~ 1880-1695$ cal BP (Carrión et

513 al., 2010b). In other palynological studies in nearby areas the spread of heathlands was found

514 since the initial stages of the Iron Age ( 2800 cal yr BP; van Mourik, 1986), while in PRD-4 it

515 was detected during the Medieval Period ( 1200 cal yr BP).

516

517 5. Conclusions

518

519 The palynological study of the PRD-4 sequence allowed us to infer the different environmental

520 factors that have affected the composition of the vegetation, and to understand the variations at

521 local and regional scales. Our results suggest that the vegetation of the studied area showed

522 multiple responses to Late Pleistocene/Holocene palaeoenvironmental changes. One was the

523 resilience of the Betula forest in an open landscape for approximately $\sim 1700$ years at the

524 beginning of the Holocene, but also other threshold, gradual and elastic responses occurred

525 with centennial delays to the initiation of the perturbations at a regional scale. This variability

526 reflects the complexity of the biotic response to environmental change and the stochastic

527 behaviour that natural systems often show across different spatial and time scales, as well as

528 their resilience and the way systems switch from one state to another.

529 With regard to the current observed and projected climate change, human-induced

530 perturbations and related vegetation dynamics, we believe that the PRD-4 record offers a good

531 example (Fig. 10) of the complexity and variability of vegetation responses (threshold, gradual,

532 elastic and resilience) to environmental perturbations since the late Pleistocene. The main

533 concern today is the impact of human-induced perturbations, not only on the landscape but

534 also on climate. Therefore a more profound knowledge of the buffering ability of ecosystems is

535 needed to predict to what extent human activities can promote drastic and unforeseen

536 changes, and to help to manage the landscape in a more sustainable way. We have to be

537 aware that the consequences of the increasing human-induced perturbations might be yet to

538 come. In this sense, long-term ecological research is a necessary tool to reconstruct the history

539 of ecosystems and its complexities.

540 The application of principal component analysis on the transposed data matrices

541 (PCA $\left.A_{t r}\right)$ of palynological data seems to be appropriate to obtain information on the structure of

542 the variance of the palynological composition of the samples, resulting in lower

543 dimensions/groupings than the constrained cluster analysis. PCA tr proved to be a valuable tool

544 to identify the type of responses of the vegetation to environmental change. Nonetheless, a

545 systematic comparison with other techniques is necessary to fully understand the advantages 
546 and drawbacks of this approach. Moreover, in the studied record the responses usually

547 coincided with the boundaries of the palynological zones, although some of the boundaries did

548 not reflect a real change or reorganization in the composition of the vegetation.

549

\section{Acknowledgements}

551

552 Lourdes López-Merino is currently supported by a post-doctoral research grant of the Spanish

553 Government at Brunel University (UK). This work was funded by the projects CDS2007-00058

554 and PGIDT02CCP60601. We are grateful to Cruz Ferro Vázquez, Manuela Costa Casais and

555 Felipe Criado (Incipit, CSIC) for their collaboration and assistance during different stages of the

556 research, and to Suzanne Leroy and Andrew Russell (Brunel University) for their comments

557 and advice on earlier versions of the manuscript. We also want to thank the reviewers, Lydie

558 Dupont and Tim Mighall, for their constructive remarks and comments that helped to improve

559 the ideas and structure of the manuscript. LLM is indebted to Alejandro Couce for his never-

560 ending encouragement and clever ideas. 


\section{References}

Allen, J.R.M., Huntley, B., Watts, W.A., 1996. The vegetation and climate of northwest Iberia over the last 14000 years. Journal of Quaternary Science 11, 125-147.

Bernhardt-Römermann, M., Gray, A., Vanbergen, A.J., Bergès, L., Bohner, A., Brooker, R.W., De Bruyn, L., De Cinti, B., Dirnböck, T., Grandin, U., Hester, A.J., Kanka, R., Klotz, S., Loucougaray, G., Lundin, L., Matteucci, G., Mészáros, I., Oláh, V., Preda, E., Prévosto, B., Pykl, J., Schmidt, W., Taylor, M.E., Vadineanu, A., Waldmann, T., Stadler, J., 2011. Functional traits and local environment predict vegetation responses to disturbance: a pan-European multi-site experiment 99, 777-787.

Birks, H.J.B., 1985. Recent and possible future mathematical developments in quantitative palaeoecology. Palaeogeography, Palaeoclimatology, Palaeoecology 50, 107-147.

Blaauw, M., 2010. Methods and code for 'classical' age-modelling of radiocarbon sequences. Quaternary Geochronology 5, 512-518.

Blackford, J.J., Innes, J.B., Hatton, J.J., Caseldine, C.J., 2006. Mid-Holocene environmental change at Black Ridge Brook, Dartmoor, SW England: a new appraisal based on fungal spore analysis. Review of Palaeobotany and Palynology 141, 189-201.

Carrión, J.S., 2002. Patterns and processes of Late Quaternary environmental change in a montane region of southwestern Europe. Quaternary Science Reviews 21, 2047-2066.

Carrión, J.S., Andrade. A., Bennett, K.D., Navarro, C., Munuera, M., 2001. Crossing forest thresholds: inertia and collapse in a Holocene sequence from south-central Spain. The Holocene 11, 635653.

Carrión, J.S., Fernández, S., González-Sampériz, P., Gil-Romera, G., Badal, E., Carrión-Marco, Y., López-Merino, L., López-Sáez, J.A., Fierro, E., Burjachs, F., 2010a. Expected trends and surprises in the Lateglacial and Holocene vegetation history of the Iberian Peninsula and Balearic Islands. Review of Palaeobotany and Palynology 162, 458-475.

Carrión, Y., Kaal, J., López-Sáez, J.A., López-Merino, L., Martínez Cortizas. A., 2010b. Holocene vegetation change in NW Spain revealed by anthracological and palynological records from a colluvial soil. The Holocene 20, 53-66.

Costa Casais, M., Martínez Cortizas, A., Pontevedra-Pombal, X., Criado Boado, F., 2009. Analysis of landforms in geoarchaeology: Campo Lameiro, NW Iberian Peninsula. Memorie Descrittive della Carta Geologica d'Italia 86, 39-50.

Dearing, J.A., 2008. Landscape change and resilience theory: a palaeoenvironmental assessment from Yunnan, SW China. The Holocene 18, 117-127.

Desprat, S., Sánchez Goñi, M.F., Loutre, M.-F., 2003. Revealing climatic variability of the last three millennia in northwestern lberia using pollen influx data. Earth and Planetary Science Letters 213, 63-78.

Feurdean, A., Willis, K.J., Parr, C.L., Tantau, I., Farcas, S., 2010. Post-glacial patterns in vegetation dynamics in Romania: homogenization or differentiation? Journal of Biogeography 37, 2197, 2208.

Foster, D.R., Zebryk, T.M., 1993. Long-term vegetation dynamics and disturbance history of a Tsugadominated forest in New England. Ecology 74, 982-998.

García-Amorena, I., Gómez-Manzaneque, F., Rubiales, J.M., Granja, H.M., Soares de Carvalho, G., Morla, C., 2007. The Late Quaternary coastal forests of western Iberia: A study of their macroremains. Palaeogeography, Palaeoclimatology, Palaeoecology 254, 448-461.

Gil-Romera, G., López-Merino., L., Carrión, J.S., González-Sampériz, P., Martín-Puertas, C., LópezSáez, J.A., Fernández, S., García Antón, M., Stefanova, V., 2010a. Interpreting resilience through long-term ecology: potential insights in western Mediterranean landscapes. The Open Ecology Journal 3, 43-53.

Gil-Romera, G., Lamb, H.F., Turton, D., Sevilla-Callejo, M., Umer, M., 2010b. Long-term resilience, bush encroachment patterns and local knowledge in a Northeast African savanna. Global Environmental Change 20,612-626.

Goeury, C., de Beaulieu, J.L., 1979. À propos de la concentration du pollen à l'aide de la liqueur de Thoulet dans le sédiments minéraux. Pollen et Spores 21, 239-251. 
Grimm, E.C., 1987. CONISS: a Fortran 77 program for stratigraphically constrained cluster analysis by the method of incremental sum of squares. Computers \& Geosciences 13, 13-35.

Grimm, E.C., 1992. Tilia version 2. Springfield. IL 62703. USA: Illinois State Museum. Research and Collection Center.

Grimm, E.C., 2004. TGView. Illinois State Museum, Springfield.

Holling, C.S., 1973. Resilience and stability of ecological systems. Annual Review of Ecology and Systematics 4, 1-23.

Jalut, G., Turu i Michels, V., Dedoubat, J-J., Otto, T., Ezquerra, J., Fontugne, M., Belet, J.M., Bonnet, L., García de Celis, A., Redondo-Vega, J.M., Vidal-Romaní, J.R., Santos, L., 2010. Palaeoenvironmental studies in NW Iberia (Cantabrian Range): Vegetation history and synthetic approach of the last deglaciation phases in the western Mediterranean. Palaeogeography, Palaeoclimatology, Palaeoecology 297, 330-350.

Kaal, J., 2011. Identification, molecular characterisation and significance of fire residues in colluvial soils from Campo Lameiro (NW Spain). PhD. Dissertation, Universidad de Santiago de Compostela, http://dspace.usc.es/handle/10347/3078, pp. 211.

Kaal, J., Martínez Cortizas, A., Eckmeier, E., Costa Casais, M., Santos Estévez, M., Criado Boado, F., 2008. Holocene fire history of black colluvial soils revealed by pyrolysis-GC/MS: a case study from Campo Lameiro (NW Spain). Journal of Archaeological Science 35, 2133-2143.

Kaal, J., Carrión Marco, Y., Asouti, E., Martín Seijo, M., Martínez Cortizas, A., Costa Casáis, M., Criado Boado, F., 2011. Long-term deforestation in NW Spain: linking the Holocene fire history to vegetation change and human activities. Quaternary Science Reviews 20, 161-175.

Leira, M., Santos, L., 2002. An early Holocene short climatic event in the northwest Iberian Peninsula inferred from pollen and diatoms. Quaternary International 93-94, 3-12.

López-Merino, L., Martínez Cortizas, A., López-Sáez, J.A., 2010a. Early agriculture and palaeoenvironmental history in the North of the Iberian Peninsula: a multi-proxy analysis of the Monte Areo mire (Asturias, Spain). Journal of Archaeological Science 37, 1978-1988.

López-Merino, L., Peña-Chocarro, L., Ruiz-Alonso, M., López-Sáez, J.A., Sánchez-Palencia, F.J., 2010b. Beyond nature: the management of a productive cultural landscape in Las Médulas (León, Spain). Plant Biosystems 144, 905-919.

López-Merino, L., Moreno, A., Leira, M., Sigró, J., González-Sampériz, P., Valero-Garcés, B.L., LópezSáez, J.A., Brunet, M., Aguilar, E., 2011a. Two hundred years of environmental change in Picos de Europa National Park inferred from sediments of Lago Enol, northern Iberia. Journal of Paleolimnology 46, 453-467.

López-Merino, L., Martínez Cortizas, A., López-Sáez, J.A., 2011b. Human-induced changes on wetlands: a study case from NW Iberia. Quaternary Science Reviews 30, 2745-2754.

López-Sáez, J.A., Parcero Oubiña, C., Lima Oliveira, E., López García, P., Criado Boalo, F., Macías Rosado, R., Martínez Cortizas, A., Franco Maside, S., 2003. Paleopaisajes concretos: polen, suelos y arqueología del yacimiento de As Pontes (Abadín, Lugo). Trabajos de Prehistoria 60, 139-151.

López-Sáez, J.A., López-Merino, L., Pérez Díaz, S., Parcero Oubiña, C., Criado Boado, F., 2009. Contribución a la caracterización de los espacios agrarios castreños: documentación y análisis palinológico de una posible terraza de cultivo en el castro de Follente (Caldas de Reis, Pontevedra). Trabajos de Prehistoria 66, 171-182.

Martínez Cortizas, A., Pérez Alberti, A., 1999. Atlas climático de Galicia. Xunta de Galicia, Santiago de Compostela, $250 \mathrm{pp}$.

Martínez Cortizas, A., Pontevedra Pombal, X., Nóvoa Muñoz, J.C., García-Rodeja, E., Shotyk, W., 1999. Mercury in a Spanish peat bog: archive of climate change and atmospheric metal deposition. Science 284, 939-942.

Martínez Cortizas, A., Mighall, T., Pontevedra-Pombal, X., Nóvoa Muñoz, J.C., Peiteado Varela, E., Piñeiro Rebolo, R., 2005. Linking changes in atmospheric dust deposition, vegetation change and human activities in northwest Spain during the last 5300 years. The Holocene 15, 698-706.

Martínez Cortizas, A., Costa-Casais, M., López-Sáez, J.A., 2009. Environmental change in NW Iberia between 7000 and 500 cal BC. Quaternary International 200, 77-89.

Mayewski, P.A., Rohling, E.E., Stager, J.C., Kalén, W., Maasch, KA., Meeker, L.D., Meyerson, E.A., Gasse, F., van Kreveld, S., Holmgren, K., Lee-Thorp, J., Rosqvist, G., Rack, F., Staubwasser, 
M., Schneider, R.R., Stegi, E.J., 2004. Holocene climate variability. Quaternary Research 62, 243-255.

Mighall, T.M., Martínez Cortizas, A., Biester, H., Turner, S.E., 2006. Proxy climate and vegetation changes during the last five millennia in NW Iberia: pollen and non-pollen palynomorph data from two ombrotrophic peat bogs in the North Western Iberian Peninsula. Review of Palaeobotany and Palynology 141, 203-223.

Moore, P.D., Webb, J.A., Collinson, M.E., 1991. Pollen analysis. 2nd edition, London: Blackwell Scientific Publications.

Morales-Molino, C., García Antón, M., Morla, C., 2011. Late Holocene vegetation dynamics on an Atlantic-Mediterranean mountain in NW Iberia. Palaeogeography, Palaeoclimatology, Palaeoecology 302, 323-337.

Moreno, A., López-Merino, L., Leira, M., Marco-Barba, J., González-Sampériz, P., Valero-Garcés, B.L., López-Sáez, J.A., Santos, L., Mata, P., Ito, E., 2011. Revealing the last 13,500 years of environmental history from the multiproxy record of a mountain lake (Lago Enol, northern Iberian Peninsula). Journal of Paleolimnology 46, 327-349.

Muñoz Sobrino, C., Ramil-Rego, P., Rodríguez Guitián, M., 1997. Upland vegetation in the north-west Iberian Peninsula after the last glaciation: forest history and deforestation dynamics. Vegetation History and Archaeobotany 6, 215-233.

Muñoz Sobrino, C., Ramil-Rego, P., Rodríguez Guitián, M., 2001. Vegetation in the mountains of northwest Iberia during the last glacial-interglacial transition. Vegetation History and Archaeobotany 10, 7-21.

Muñoz Sobrino, C., Ramil-Rego, P., Gómez-Orellana, L., 2004. Vegetation of the Lago de Sanabria area (NW Iberia) since the end of the Pleistocene: a palaeoecological reconstruction on the basis of two new pollen sequences. Vegetation History and Archaeobotany 13, 1-22.

Muñoz Sobrino, C., Ramil-Rego, P., Gómez-Orellana L., Díaz Varela, R.A., 2005. Palynological data on major Holocene climatic events in NW Iberia. Boreas 34, 381-400.

Muñoz Sobrino, C., García-Gil, S., Diez, J.B., Iglesias, J., 2007a. Palynological characterization of gassy sediments in the inner part of Ría de Vigo (NW Spain). New chronological and environmental data. Geo-Marine Letters 27, 289-302.

Muñoz Sobrino, C., Ramil-Rego, P., Gómez-Orellana, L., 2007b. Late Würm and early Holocene in the mountains of northwest Iberia: biostratigraphy, chronology and tree colonization. Vegetation History and Archaeobotany 16, 223-240.

Ramil-Rego, P., Muñoz-Sobrino, C., Rodríguez-Guitián, M., Gómez-Orellana, L., 1998. Differences in the vegetation of the North Iberian Peninsula during the last 16,000 years. Plant Ecology 138, 41-62.

Reille, M., 1992. Pollen et Spores d'Europe et d'Afrique du Nord. Laboratoire de Botanique Historique et Palynologie, Marseille.

Reimer, P.J., Baillie, M.G.L., Bard, E., Bayliss, A., Beck, J.W., Blackwell, P.G., Bronk Ramsey, C., Buck, C.E., Burr, G.S., Edwards, R.L., Friedrich, M., Grootes, P.M., Guilderson, T.P., Hajdas, I., Heaton, T.J., Hogg, A.G., Hughen, K.A., Kaiser, K.F., Kromer, B., McCormac, F.G., Manning, S.W., Reimer, R.W., Richards, D.A., Southon, J.R., Talamo, S., Turney, C.S.M., van der Plicht, J., Weyhenmeyer, C.E., 2009. IntCal09 and Marine09 radiocarbon age calibration curves, 050,000 years cal BP. Radiocarbon $51,1111-1150$.

Ritchie, J.C., 1986. Climate change and vegetation response. Vegetatio 67, 65-74.

Salvo, E., 1990. Guía de helechos de la Península lbérica y Baleares. Ediciones Pirámide, Madrid.

Santos, L., Sánchez-Goñi, M.F., 2003. Lateglacial and Holocene environmental changes in Portuguese coastal lagoons 3: vegetation history of the Santo André coastal area. The Holocene 13, 459464.

Schellekens, J., Buurman, P., Fraga, I., Martínez Cortizas, A., 2011. Holocene vegetation and hydrologic changes inferred from molecular vegetation markers in peat, Penido Vello (Galicia, Spain). Palaeogeography, Palaeoclimatology, Palaeoecology 299, 56-69.

Silva Sánchez, N., 2010. Cambios ambientales en los últimos 3000 años en el sector occidental de la Sierra del Bocelo a partir de indicadores geoquímicos y palinológicos. Tesina. Universidad de Santiago de Compostela. 
Tinner, W., Conedera, M., Gobet, E., Hubschmid, P., Wehrli, M., Ammann, B. 2000. A palaeoecological attempt to classify fire sensitivity of trees in the Southern Alps. The Holocene 10, 565-574. van Geel, B. 1978., A palaeoecological study of Holocene peat bog sections in Germany and the Netherlands, based on the analysis of pollen, spores and macro- and microscopic remains of fungi, algae, cormophytes and animals. Review of Palaeobotany and Palynology 25, 1-120. van Mourik, J.M., 1986. Pollen profiles of slope deposits in the Galician area (N.W. Spain). KNAGNederlandse Geografische Studies 012, Amsterdam, pp. 171.

Williams, J.W., Blois, J.L., Shuman, B.N., 2011. Extrinsic and intrinsic forcing of abrupt ecological change: case studies from the late Quaternary. Journal of Ecology 99, 664-677.

Willis, K.J., Bailey, R.M., Bhagwat, S.A., Birks, H.J.B., 2010. Biodiversity baselines, thresholds and resilience: testing predictions and assumptions using palaeoecological data. Trends in Ecology and Evolution 25, 583-591.

Yeloff, D., Charman, D., van Geel, B., Mauquoy, D., 2007. Reconstruction of hydrology, vegetation and past climate change in bogs using fungal microfossils. Review of Palaeobotany and Palynology 146, 102-145. 


\section{Tables and table captions}

Table 1. Results of ${ }^{14} \mathrm{C}$ dating, showing calibrated age ranges $(2 \sigma)$ in cal yr BP.

Table 1

\begin{tabular}{|llllll|}
\hline Sample & Depth $(\mathrm{cm})$ & Lab code & ${ }^{14} \mathrm{C}$ age BP & Age cal yr BP & Probability (\%) \\
\hline PRD-4-02 & $5-10$ & Ua-34719 & $104.3 \pm 0.4 \mathrm{pM}$ & modern & $\sim$ \\
\hline PRD-4-06 & $25-30$ & Beta-297739 & $850 \pm 30$ & $690-797$ & 89.4 \\
& & & & $820-820$ & 0.1 \\
& & & & $871-897$ & 5.4 \\
\hline PRD-4-14 & \multirow{6}{*}{$65-70$} & Beta-299229 & \multirow{2}{*}{$3080 \pm 30$} & $3219-3231$ & 2.9 \\
& & & & $3238-3368$ & 92 \\
\hline PRD-4-20 & \multirow{2}{*}{$55-100$} & Beta-299230 & $4090 \pm 30$ & $4448-4466$ & 3.4 \\
& & & & $4518-4651$ & 65.6 \\
& & & & $4670-4701$ & 6.7 \\
& & & & $4759-4808$ & 19.2 \\
\hline PRD-4-25 & $120-125$ & Beta-297740 & $5540 \pm 40$ & $6286-6403$ & 100 \\
\hline PRD-4-39 & $190-195$ & Beta-240963 & $9760 \pm 50$ & $10910-10911$ & 0.1 \\
& & & & $11096-11258$ & 94.9 \\
\hline
\end{tabular}

Table 2. Eigenvalues and variance explained by the principal components obtained by PCA analysis of the transposed data matrix of local taxa (hydro-hygrophytes and NPP).

Table 2

\begin{tabular}{|lllllll|}
\hline \multicolumn{3}{l}{ PCA Local taxa } \\
\hline & \multicolumn{1}{l|}{ Initial Eigenvalues } & \multicolumn{4}{l|}{ Rotation Sums of Squared Loadings } \\
\hline Component & Total & $\%$ Variance & Cumulative \% & Total & $\%$ Variance & Cumulative \% \\
\hline PC1 & 25.4 & 54.0 & 54.0 & 19.9 & $\mathbf{4 2 . 3}$ & 42.3 \\
PC2L & 9.8 & 20.9 & 74.9 & 11.0 & 23.4 & 65.7 \\
PC3L & 4.6 & 9.8 & 84.7 & 6.7 & 14.3 & 80.0 \\
PC4 & 3.1 & 6.6 & 91.3 & 5.1 & 10.9 & 91.0 \\
PC5 & 1.3 & 2.8 & 94.1 & 1.5 & 3.1 & 94.1 \\
\hline
\end{tabular}

Extraction method: Principal Component Analysis with Varimax rotation.

Table 3. Eigenvalues and variance explained by the principal components obtained by PCA analysis of the transposed data matrix of regional pollen indicators.

Table 3

\begin{tabular}{|c|c|c|c|c|c|c|}
\hline \multicolumn{7}{|c|}{ PCA Regional taxa } \\
\hline \multirow{2}{*}{ Component } & \multicolumn{3}{|c|}{ Initial Eigenvalues } & \multicolumn{3}{|c|}{ Rotation Sums of Squared Loadings } \\
\hline & Total & $\%$ Variance & Cumulative $\%$ & Total & $\%$ Variance & Cumulative $\%$ \\
\hline$P C 1_{R}$ & 30.3 & 64.5 & 64.5 & 19.9 & 42.4 & 42.4 \\
\hline$P C 2_{R}$ & 7.3 & 15.5 & 80.0 & 12.9 & 27.5 & 69.9 \\
\hline$P C 3_{R}$ & 5.1 & 10.9 & 90.9 & 7.0 & 14.8 & 84.7 \\
\hline PC4R & 2.7 & 5.7 & 96.6 & 5.6 & 11.9 & 96.6 \\
\hline
\end{tabular}

Extraction method: Principal Component Analysis with Varimax rotation. 


\section{Figure captions}

Figure 1. Location of the study area in NW Spain.

Figure 2. PRD-4 soil stratigraphy (courtesy of Manuela Costa Casais) and charcoal concentration (Kaal et al., 2011).

Figure 3. Age-depth model of the PRD-4 sequence, fitted with a smooth-spline function using Clam (Blaauw, 2010). Red blocks show $95 \%$ the highest posterior density ranges

Figure 4. Local (hydro-hygrophytes and NPP) palynological diagram. The filled silhouettes show the percentage curves of the taxa, while the open silhouettes show the $5 x$ exaggeration curves. CONISS cluster analysis together with the Local Assemblage Zones (LAZ), and the estimated chronology are plotted as well. Values of hydro-hygrophytes and NPP are expressed as percentages of the total land pollen sum (trees, shrubs and herbs).

Figure 5. Squared factor loadings of the five principal components (transposed matrix) explaining the variation of the local signal of PRD-4 soil sequence.

Figure 6. Factor scores of the five local principal components (transposed matrix) obtained for the local signal of PRD-4 soil sequence.

Figure 7. Regional (total land pollen sum) palynological diagram. The filled silhouettes show the percentage curves of the taxa, while the open silhouettes show the $5 x$ exaggeration curves. CONISS cluster analysis together with the Regional Assemblage Zones (RAZ), and the estimated chronology are plotted as well. Values of trees, shrubs and herbs are expressed as percentages of the total land pollen sum, meaning the sum of these three groups.

Figure 8. Squared factor loadings of the four principal components (transposed matrix) explaining the variation of the regional signal of PRD-4 soil sequence.

Figure 9. Factor scores of the four regional principal components (transposed matrix) obtained for the regional signal of PRD-4 soil sequence.

Figure 10. Synthesis of the palaeoenvironmental history as inferred from the PRD-4 palynological data. The graphs to the left show the proportion of variance of each sample that can be explained by the five extracted local principal components and four regional principal components (communalities) obtained by PCA $A_{t r}$. From left to right, the remaining columns present the RAZ and LAZ, the description of local and regional vegetation composition, the type of responses, charcoal concentration and the drivers of environmental change (see text for details). 
796 Figure 1

Iberian Peninsula

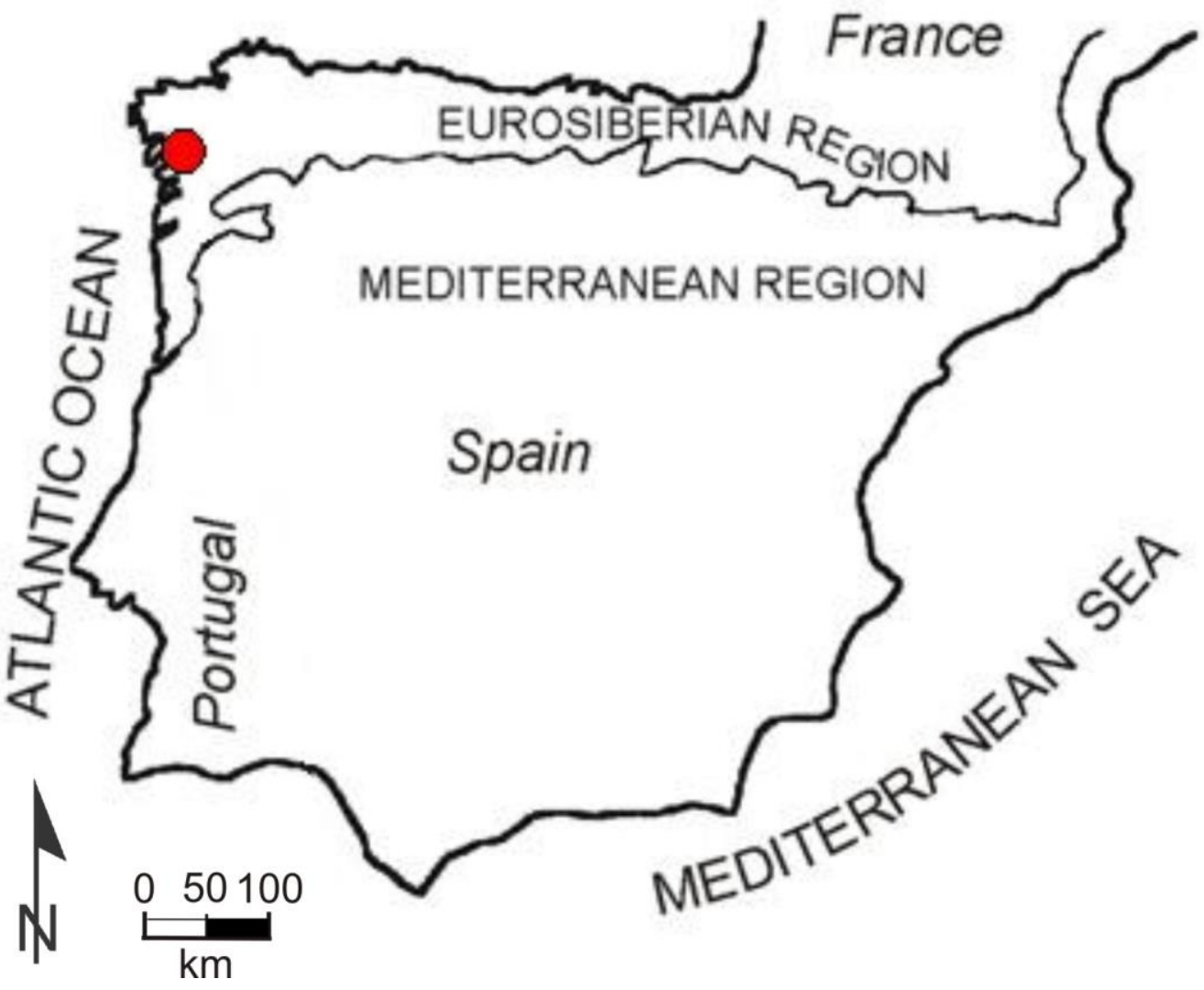




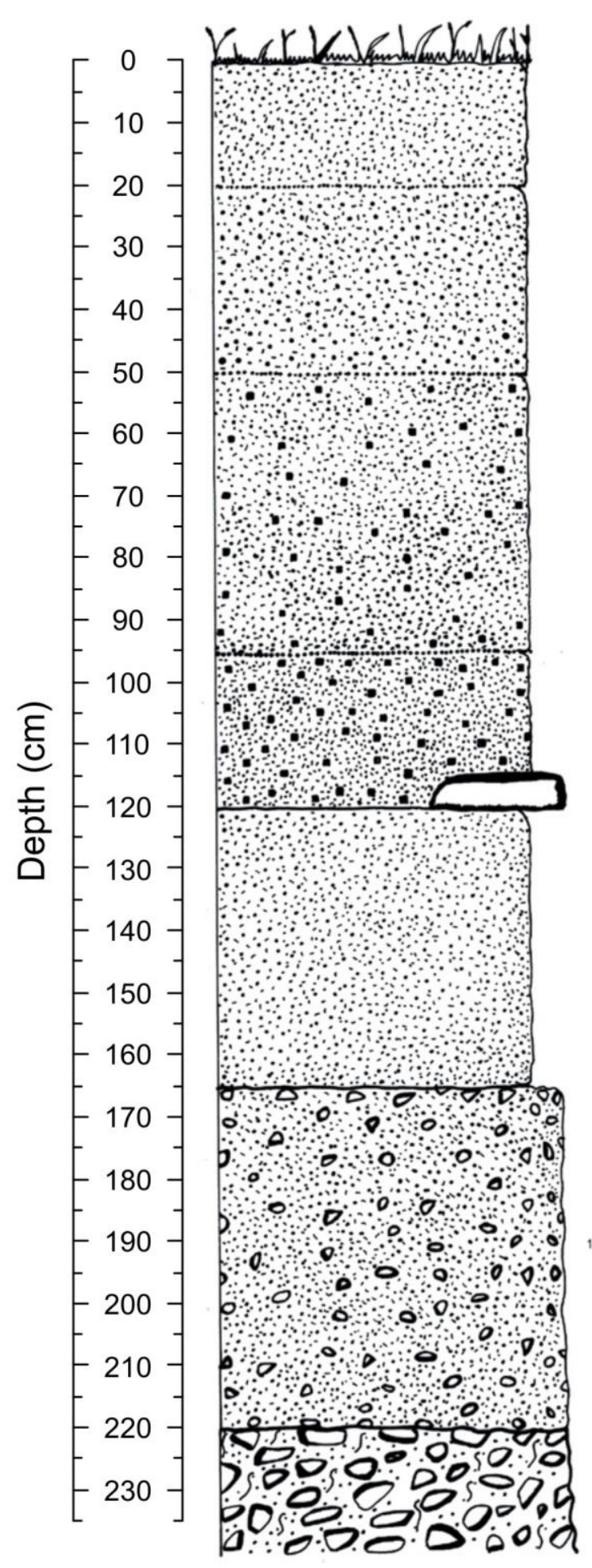

800
Charcoal

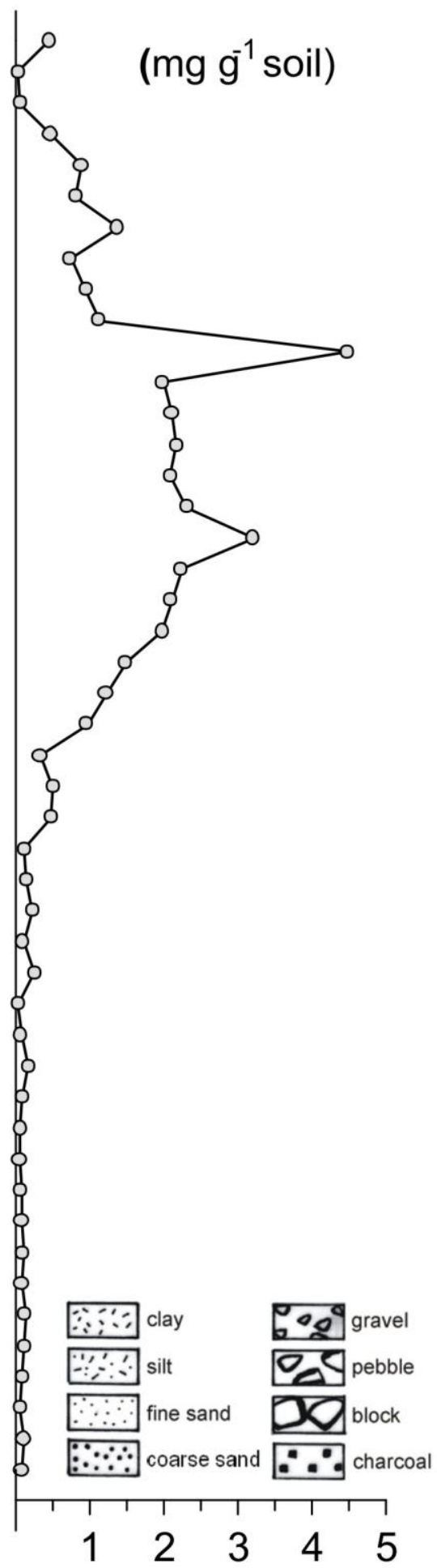

801 
$802 \quad$ Figure 3

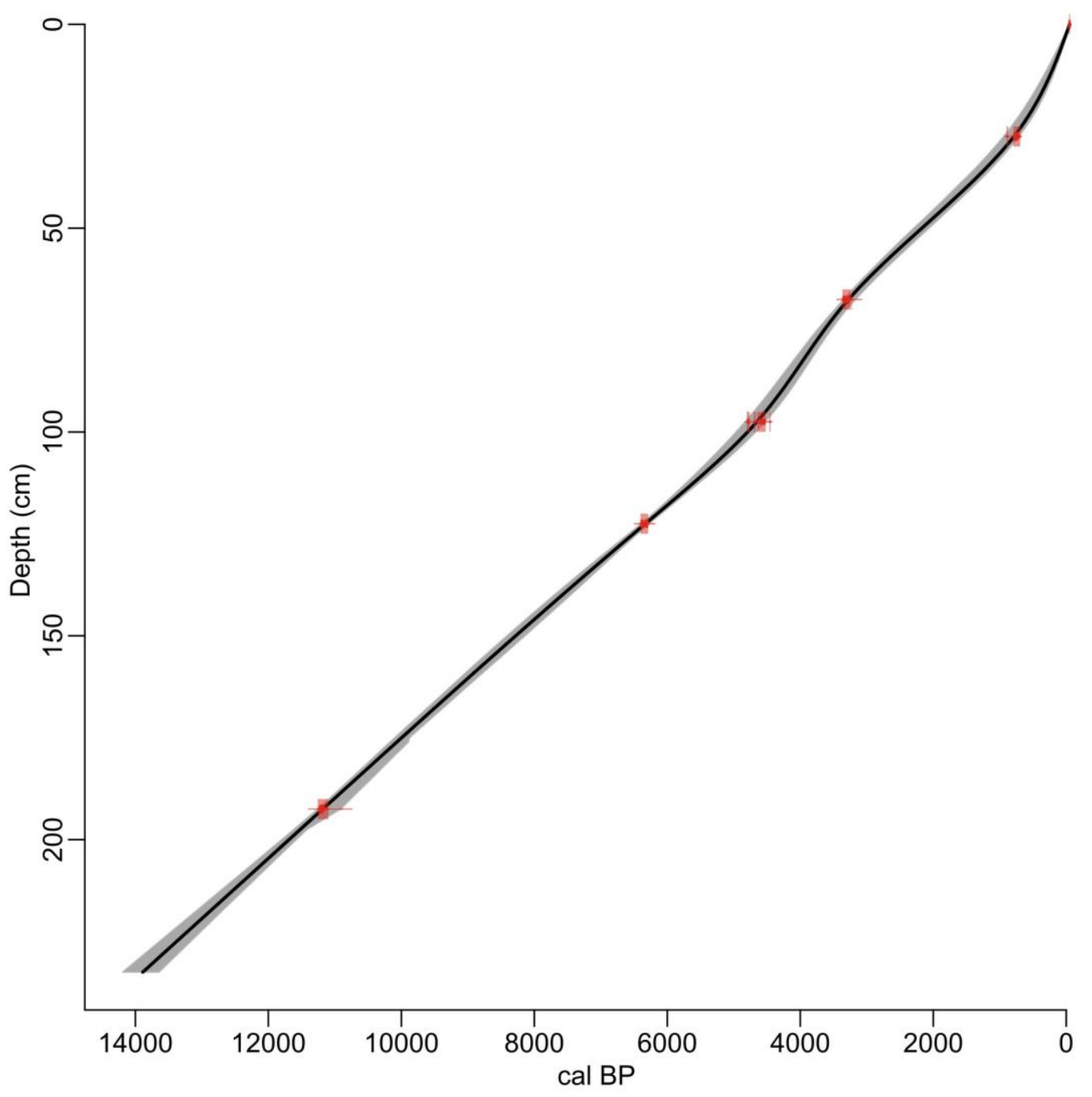

803

804 
$805 \quad$ Figure 4

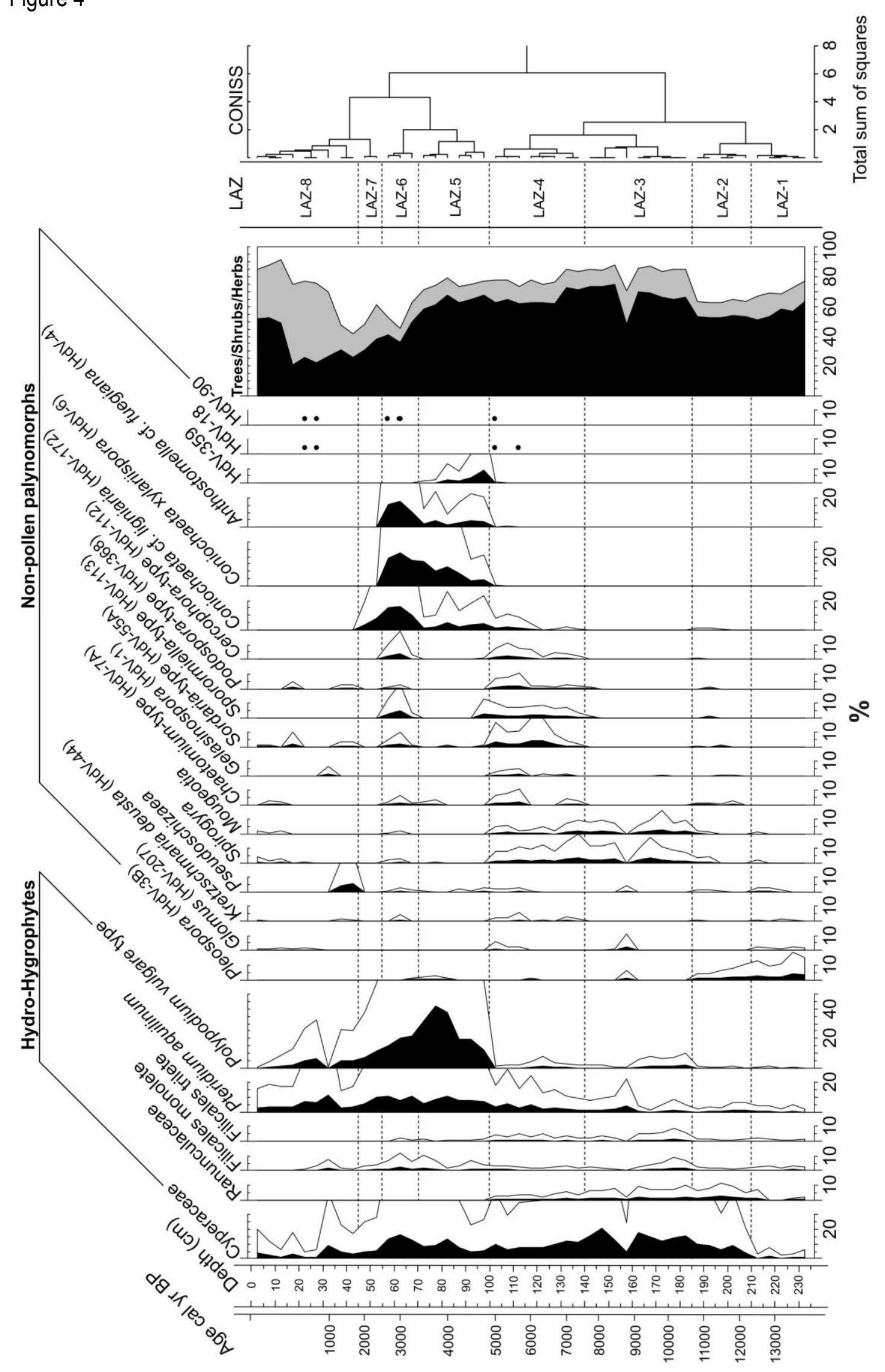


Figure 5

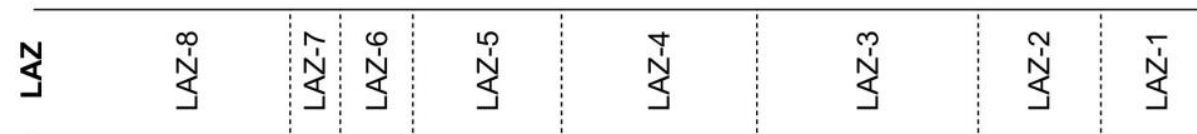
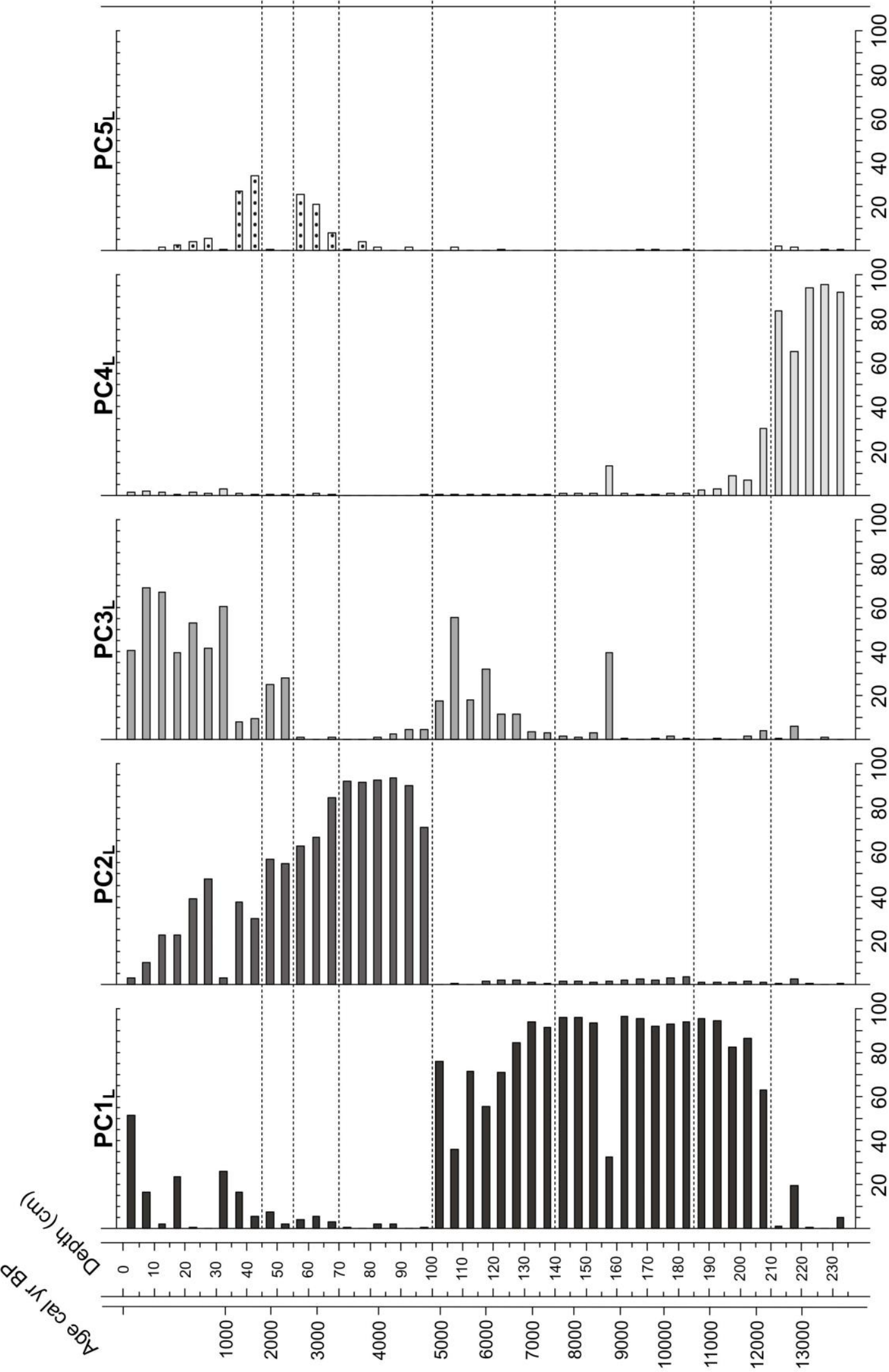
$810 \quad$ Figure 6

811

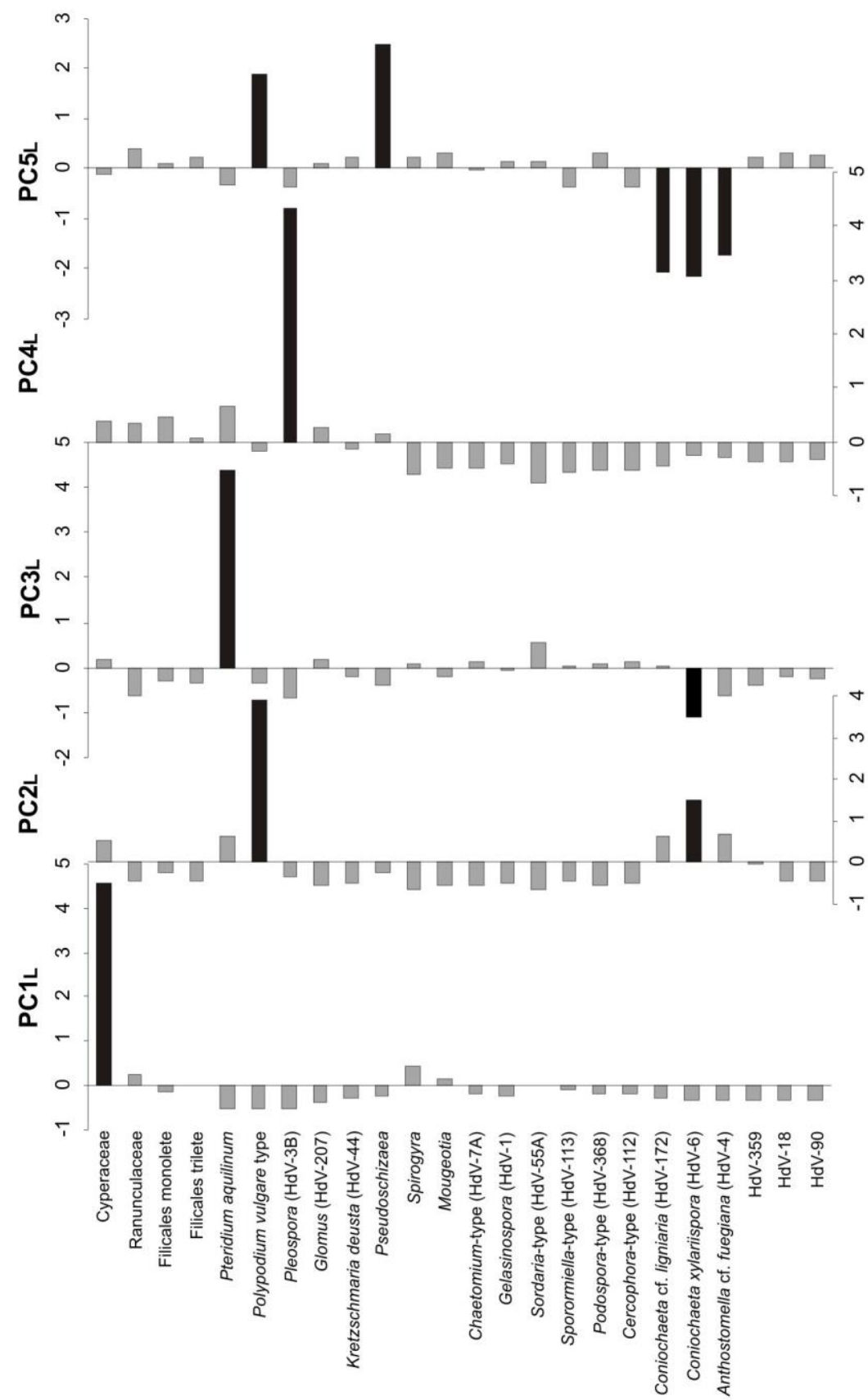

812 
Figure 7
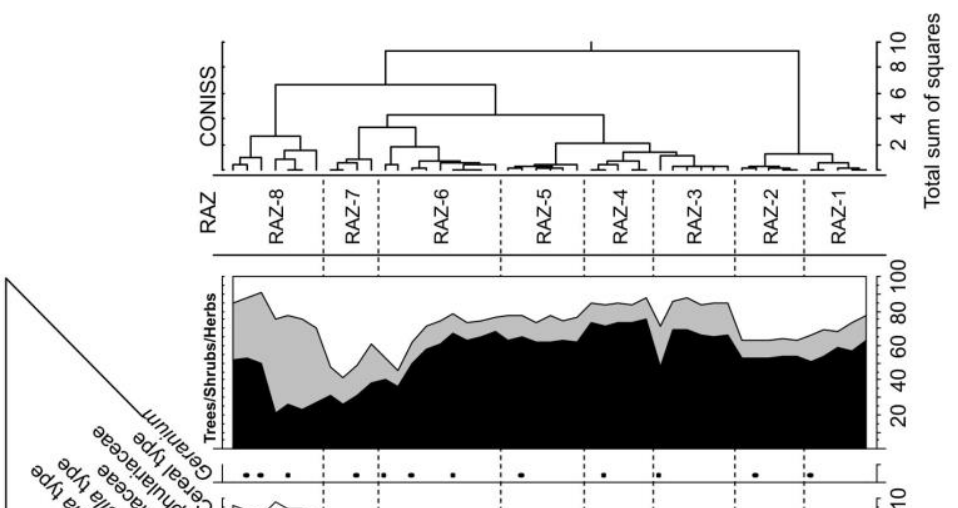

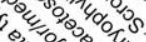

(1)

o 20

/,

(1)

-

(1)

s.'



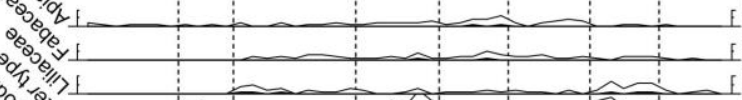

(2)

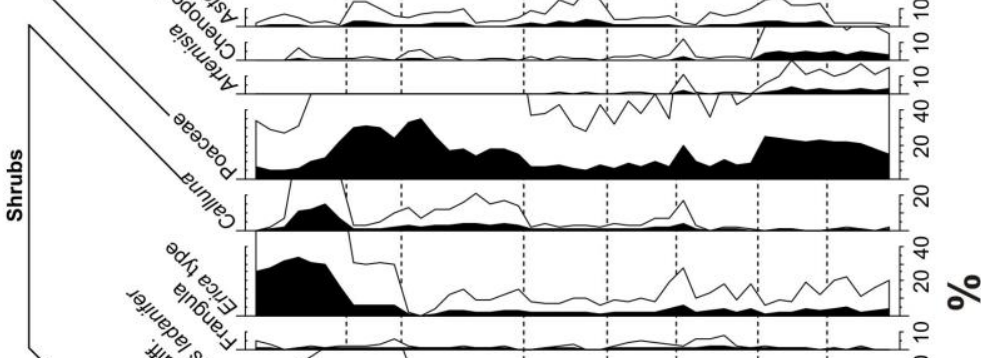

\%

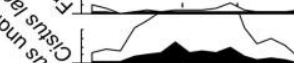

$3, \frac{13}{2}$

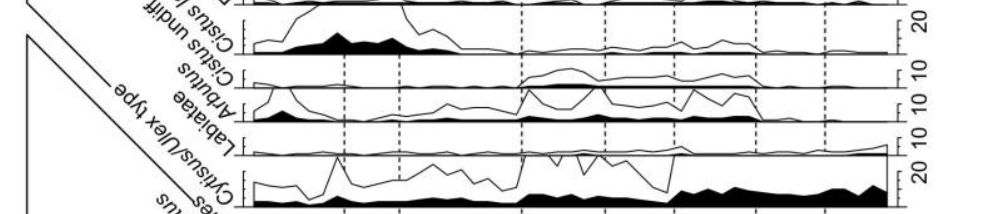

815 
$816 \quad$ Figure 8

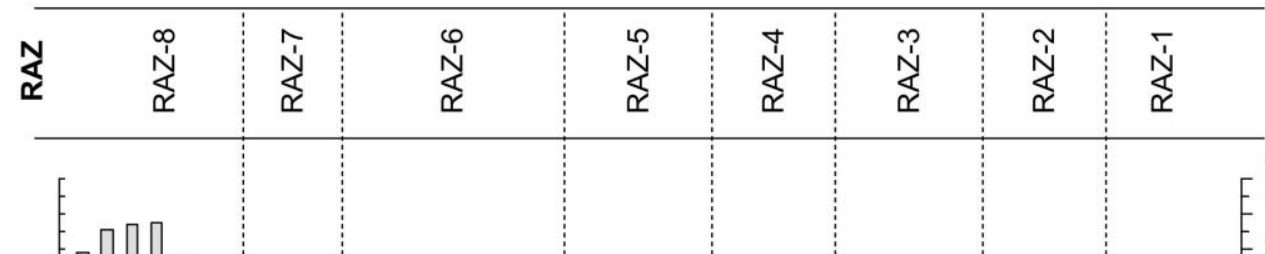
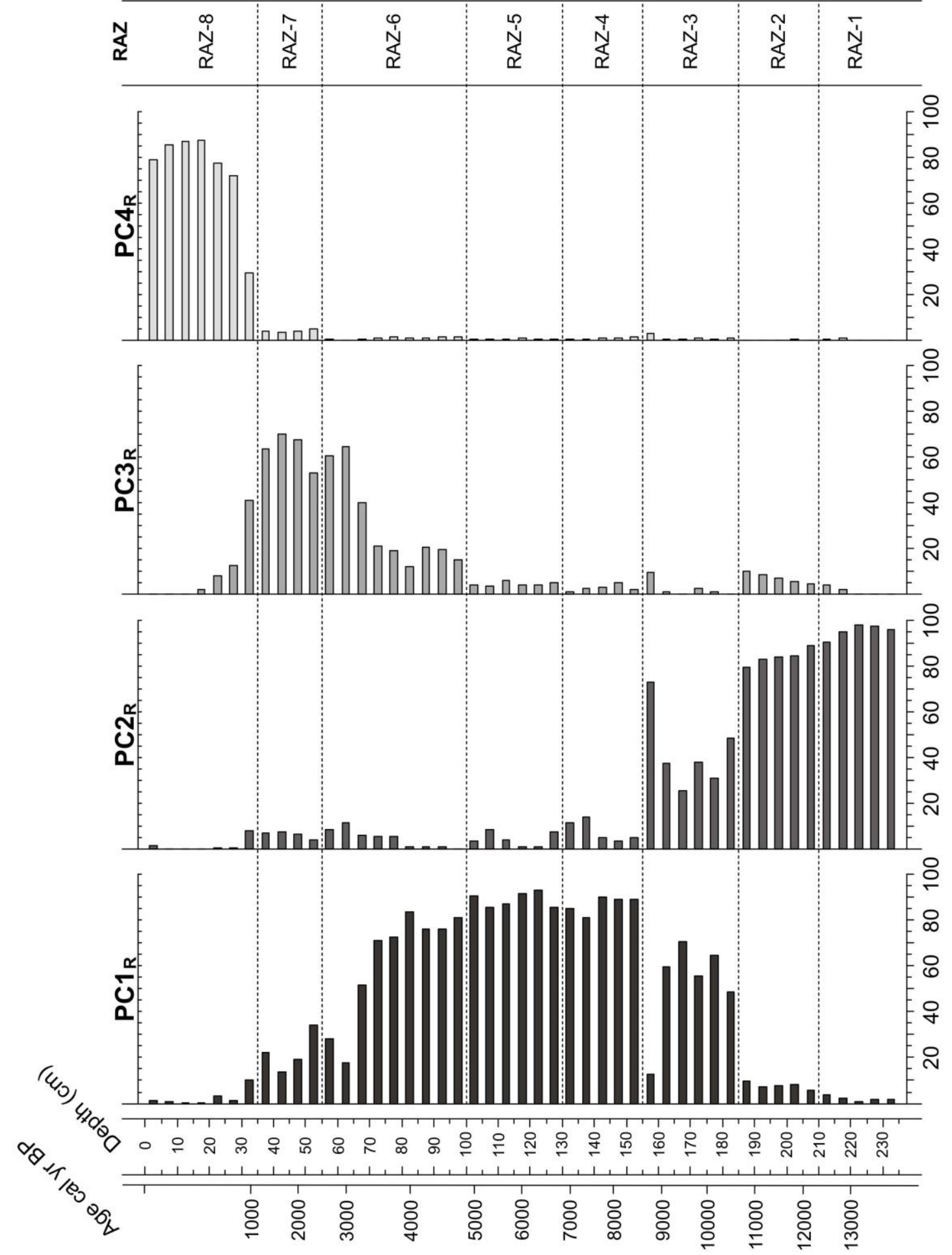

817

818 
$819 \quad$ Figure 9

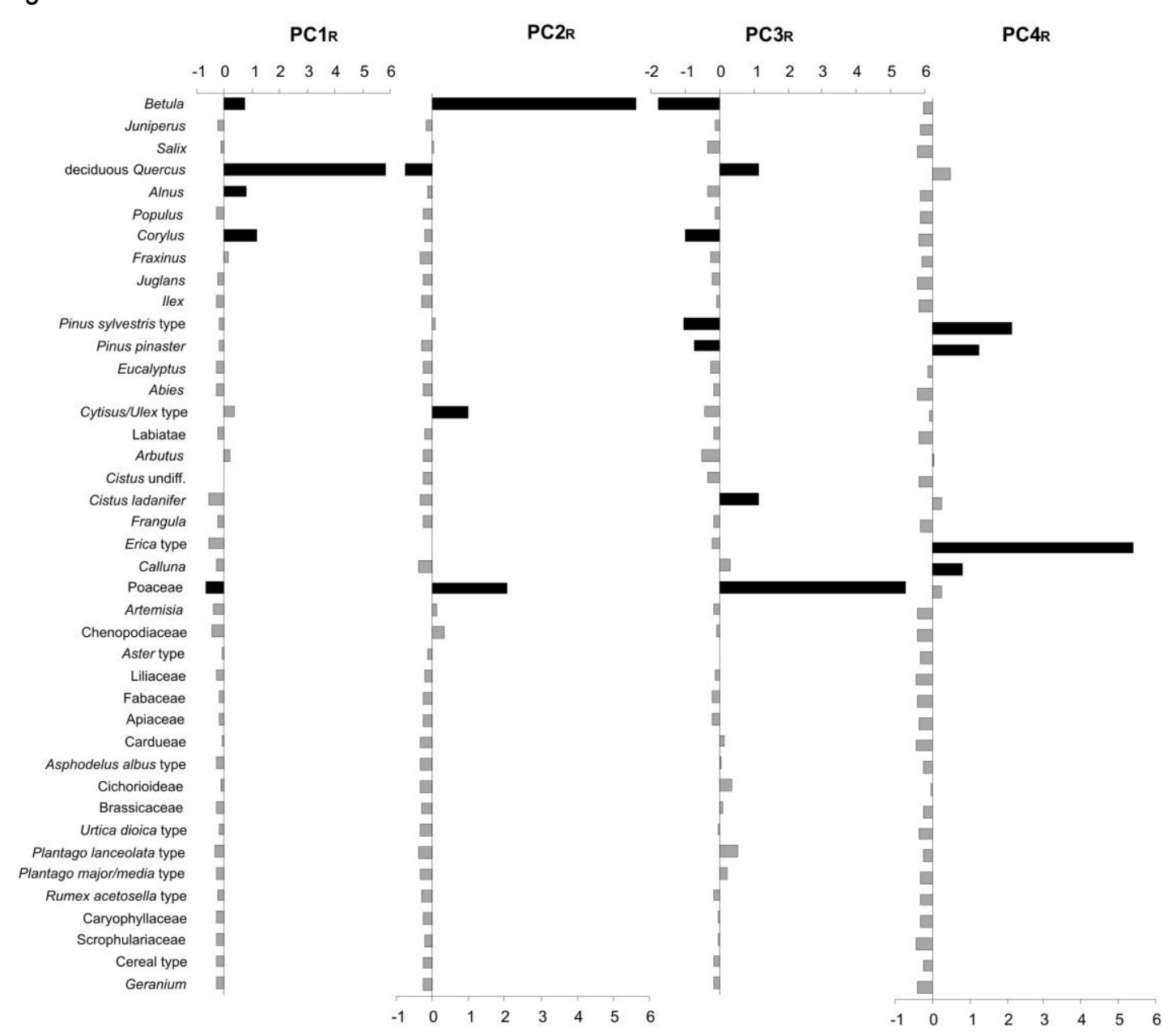

820

821 
822 Figure 10
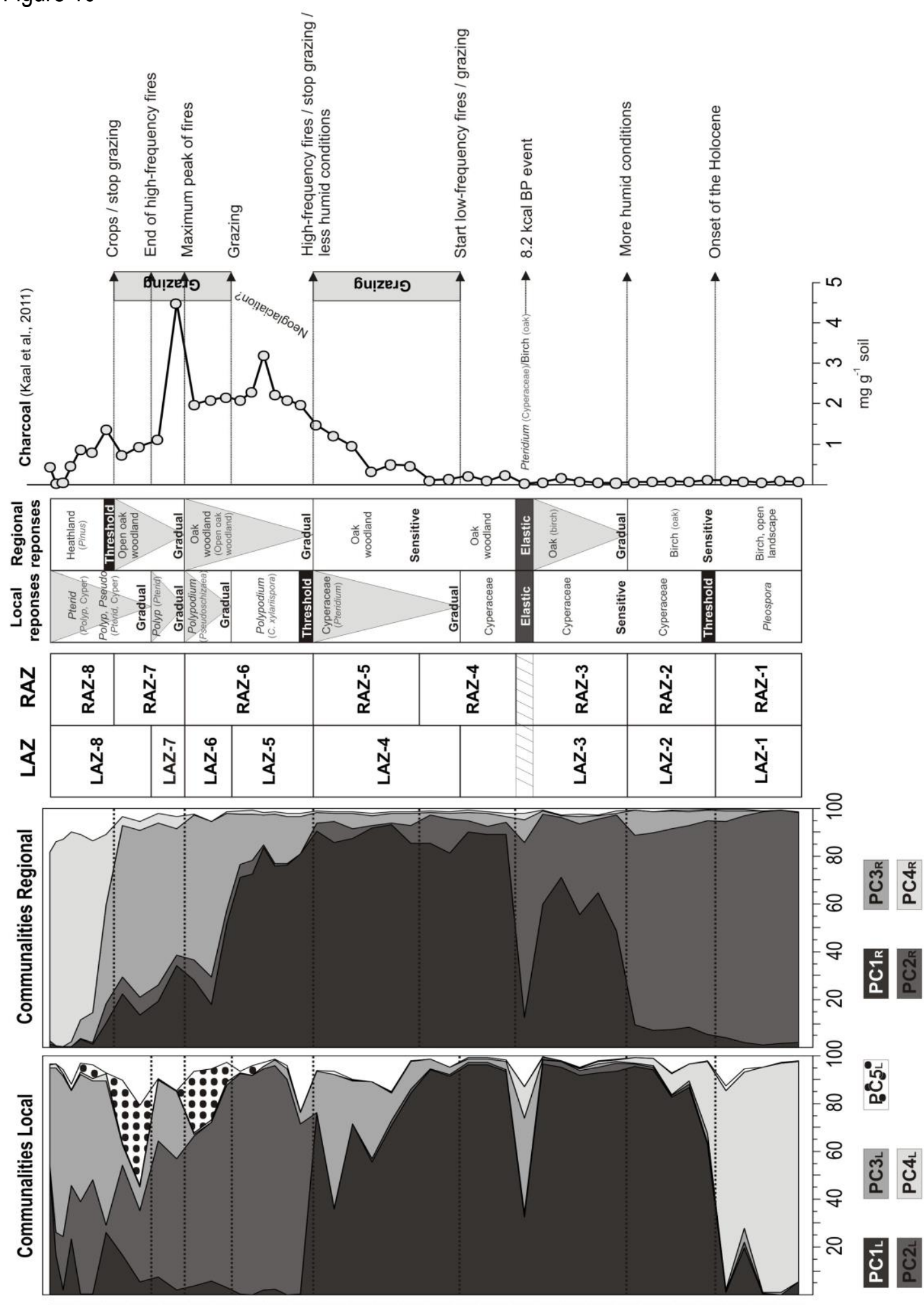

823

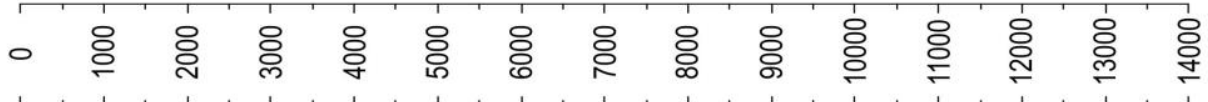

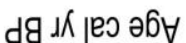

